\title{
Nutritional Risk Screening Tools for Older Adults with COVID-19: A Systematic Review
}

\author{
David Franciole Oliveira Silva ${ }^{1, *(1)}$, Severina Carla Vieira Cunha Lima ${ }^{2}$, \\ Karine Cavalcanti Mauricio Sena-Evangelista ${ }^{2}$, Dirce Maria Marchioni ${ }^{3}$ (D), \\ Ricardo Ney Cobucci 4 (D) and Fábia Barbosa de Andrade 1,* \\ 1 Postgraduate Program in Collective Health, Federal University of Rio Grande do Norte-UFRN, \\ Natal 59056-000, Brazil \\ 2 Department of Nutrition, Federal University of Rio Grande do Norte-UFRN, Natal 59078-970, Brazil; \\ scvclima@gmail.com (S.C.V.C.L.); kcmsena@gmail.com (K.C.M.S.-E.) \\ 3 Department of Nutrition, School of Public Health, University of São Paulo-USP, \\ São Paulo 05410-020, Brazil; marchioni@usp.br \\ 4 Postgraduate Program in Biotechnology, Potiguar University-UnP, Natal 59056-000, Brazil; \\ drcobucci@ufrn.edu.br \\ * Correspondence: davfranci@hotmail.com (D.F.O.S.); fabiabarbosabr@gmail.com (F.B.d.A.)
}

Received: 16 August 2020; Accepted: 24 September 2020; Published: 27 September 2020

\begin{abstract}
Coronavirus disease 2019 (COVID-19) is associated with high risk of malnutrition, primarily in older people; assessing nutritional risk using appropriate screening tools is critical. This systematic review identified applicable tools and assessed their measurement properties. Literature was searched in the MEDLINE, Embase, and LILACS databases. Four studies conducted in China met the eligibility criteria. Sample sizes ranged from six to 182, and participants' ages from 65 to 87 years. Seven nutritional screening and assessment tools were used: the Nutritional Risk Screening 2002 (NRS-2002), the Mini Nutritional Assessment (MNA), the MNA-short form (MNA-sf), the Malnutrition Universal Screening Tool (MUST), the Nutritional Risk Index (NRI), the Geriatric NRI (GNRI), and modified Nutrition Risk in the Critically ill (mNUTRIC) score. Nutritional risk was identified in $27.5 \%$ to 100\% of participants. The NRS-2002, MNA, MNA-sf, NRI, and MUST demonstrated high sensitivity; the MUST had better specificity. The MNA and MUST demonstrated better criterion validity. The MNA-sf demonstrated better predictive validity for poor appetite and weight loss; the NRS-2002 demonstrated better predictive validity for prolonged hospitalization. mNUTRIC score demonstrated good predictive validity for hospital mortality. Most instruments demonstrate high sensitivity for identifying nutritional risk, but none are acknowledged as the best for nutritional screening in older adults with COVID-19.
\end{abstract}

Keywords: nutritional screening; nutritional risk; nutritional assessment; malnutrition; elderly; COVID-19; coronavirus

\section{Introduction}

Disease caused by the novel coronavirus 2019 (COVID-19) is currently the most serious public health issue on several continents [1]. Older age (over 65 years) has been associated with more severe disease and worse prognoses [2,3]. Factors such as the presence of comorbidities, greater propensity for systemic organ dysfunction, and poor nutritional status can contribute to the heightened risk of clinical complications in older adults with COVID-19 [4].

The course of COVID-19 presents with one severe inflammatory condition characterized by the involvement of proinflammatory cytokines [5]. Malnutrition may compromise the patient's immune 
system and, consequently, the effectiveness of treatment, resulting in greater disease severity $[6,7]$. In this sense, the early assessment of nutritional risk, defined as 'chances of a better or worse outcome from disease or surgery according to actual or potential nutritional and metabolic status' [8], can contribute to the determination of the most appropriate nutritional therapy. Thus, adequate nutrition can provide a better immune system response and a more favorable prognosis $[6,7]$.

There is no gold standard for identifying nutritional risk or malnutrition. In most cases, nutritional risk is researched via screening tools, typically applied by nutritionists, doctors, or other professionals, preceding a full nutritional assessment $[9,10]$. Tools such as the Mini Nutritional Assessment-short form (MNA-sf) [11,12], the Geriatric Nutrition Risk Index (GNRI) [13], the Nutritional Risk Screening 2002 (NRS-2002) [14], the Malnutrition Universal Screening Tool (MUST) [15], the Nutritional Risk Index (NRI) [16], the Short Nutritional Assessment Questionnaire (SNAQ) [17], and Nutrition Risk in the Critically Ill (NUTRIC) scores [18] are practical and inexpensive to apply and can predict clinical outcomes [9]. Nutritional assessment instruments, such as the Global Assessment Subjective (SGA) and the Mini Nutritional Assessment (MNA), also assess biochemical and laboratory parameters and clinical and dietetical factors [9,10]. The instruments MNA [19,20], MNA-sf $[11,12,21]$, GNRI [13,21], MUST $[15,21]$, and NRI $[16,21]$ were developed specifically to identify nutritional risk or malnutrition in older adults, and others are also used to evaluate this target population [22,23].

Identifying older adults at nutritional risk proves difficult in the intensive care unit (ICU) due to the nature of critical illness. No consensus exists on the most appropriate method to identify these patients. Traditional screening and assessment tools did not uniformly identify older adults as malnourished or at nutritional risk in the ICU and, therefore, may be inappropriate for use in this population [24].

Several studies have recorded a high prevalence of nutritional risk and malnutrition in the population over 65 years old, especially those who are hospitalized [25,26]. Researchers have thus noted the need to assess nutritional risk among older adults with COVID-19 [27]. However, to our knowledge, no systematic review has yet been published of the nutritional screening instruments that could be used to identify nutritional risk in older adults with COVID-19. Therefore, the present study aims to identify the screening instruments that can be used to assess nutritional risk in older adults with COVID-19, and to clarify their measurement properties.

\section{Materials and Methods}

This systematic review included studies published in any language between November 2019 and July 2020, and was prepared following the recommendations of the preferred reporting items for systematic reviews and meta-analyses (PRISMA) [28]. The systematic review protocol is registered in PROSPERO (CRD42020186866).

\subsection{Eligibility Criteria}

Observational studies (cross-sectional, longitudinal, case series, case-control), clinical trials, comparative studies of different nutritional risk screening instruments, or validation studies that used nutritional screening instruments to identify nutritional risk in people over 65 years of age with COVID-19 were considered eligible for inclusion in the study. Review articles were excluded.

\subsection{Databases and Search Strategy}

The literature search was conducted on July 3, 2020, using the Medical Literature Analysis and Retrieval System Online database (MEDLINE, via PubMed), the Excerpta Medica Database (Embase), and the Latin American and Caribbean Health Sciences Literature (LILACS) database using a combination of the following descriptors and their synonyms: "nutrition risk", "nutritional risk", "nutritional screening", "nutrition screening", "nutritional assessment", "nutritional index", "Geriatric Nutrition Risk Index", "Mini Nutritional Assessment", "Subjective Global Assessment", "Nutritional Risk Screening tool 2002", "Malnutrition Universal Screening Tool”, "Nutritional Risk Index", "Short 
Nutritional Assessment Questionnaire", "Nutrition Risk in Critically Ill score", and "COVID-19". Supplementary Table S1 presents the search strategy used in each database.

\subsection{Screening and Selection of Studies}

Two researchers independently (DS and SL) screened the studies. Initially, titles and abstracts were read. The full text of selected articles was then analyzed to confirm fulfillment of the study's eligibility criteria.

\subsection{Data Extraction}

The following data were extracted from the selected articles: authorship; country and period of research; type of study; number, age, and sex of participants; criteria used to diagnose COVID-19; nutritional screening instrument used; properties of the nutritional screening instrument used (sensitivity, specificity, criterion validity, predictive validity); and participants' nutritional risk information.

\subsection{Evaluation of Studies' Methodological Quality and Instruments' Properties}

The Newcastle-Ottawa scale was used to assess the methodological quality of retrospective studies [29], applying the modified version [30] to assess cross-sectional studies. The scale consists of eight questions; all are rated up to one star each, except for the question about comparability, which can be rated up to two stars. The modified version for cross-sectional studies consists of seven questions rated up to one star each, except those on questions on comparability and outcome, which can be rated up to two stars. Total scores for both versions can reach a maximum of nine stars. To assess case series studies, the instrument proposed by Murad et al. [31] was employed.

The nutritional screening instruments' properties were evaluated according to the Quality Assessment of Diagnostic Accuracy Studies (QUADAS) criteria [32], which assess four domains: patient selection, instrument testing, reference standard and flow, and time of administration. The answers to the questions in each domain can be used to identify instrument's the risk of bias and applicability [32].

\subsection{Narrative Summary of Results}

Descriptive analysis was performed to synthesize the data on the instruments' properties (criterion validity, construct validity, and predictive validity) analyzed in each study. One narrative synthesis comparing the same properties between the different nutritional risk screening instruments was conducted. The prevalence of nutritional risk and malnutrition was compared between studies, considering the instruments used in each one.

The instruments' sensitivity, specificity, positive predictive value (PPV), and negative predictive value (NPV) were evaluated. Sensitivity refers to the instrument's ability to accurately identify individuals at nutritional risk (true positive [TP]/true positive [TP] + false negative [FN]) [33]. Specificity refers to the instrument's ability to accurately identify well-nourished individuals (without malnutrition) as having no nutritional risk (true negative $[\mathrm{TN}] /$ true negative $[\mathrm{TN}]+$ false positive [FP]) [33].

PPV indicates the proportion of subjects who tested positive for nutritional risk and were actually at risk (true positive results; TP/TP + FP). NPV indicates to the proportion of subjects who tested negative for nutritional risk and were actually without risk (true negative results; TN/TN + FN) [34,35]. Sensitivity, specificity, PPV, and NPV were calculated based on the studies' true positive, true negative, false positive, and false negative results. Statistical analysis, including calculation of $95 \%$ confidence intervals (CIs), was performed using RevMan (Review Manager) version 5.3. Sensitivity and specificity levels of over $80 \%$ were classified as good; levels above $50 \%$ and up to $80 \%$ were classified as weak; levels below $50 \%$ were classified as poor [36].

Criterion or construct validity of the nutritional screening instrument was analyzed for studies that compared the nutritional screening results with a reference criterion, according to the parameter or 
criterion used for comparison. Because no gold standard has been defined for diagnosis of nutritional risk [25,37], the methods or criteria suggested by Van Bokhorst-de van der Schueren et al. [36] were considered appropriate for analysis of criterion validity: nutritional assessment and anthropometry, objective assessment by a professional, or comparison with another nutritional screening tool of reference (e.g., the MNA or SGA).

Construct validity was analyzed for studies that compared the nutritional screening results with reference standards considered to have less validity, which have differences in comparison with nutritional screening instruments $[9,36,38]$. Evaluation was conducted of the relationship between the problem diagnosis (nutritional risk) and related variables not included in the instrument, for example, by analyzing in comparison to other nutritional screening instruments, such as the MNA-sf, MUST, NRS-2002, NRI, or modified NUTRIC (mNUTRIC) score, or the results of laboratory tests, including albumin, pre-albumin, creatinine, and total lymphocyte count (TLC) [39].

Predictive validity, referring to the screening tool's ability to predict clinical outcomes, was assessed according to cutoff points of the area under the curve (AUC). When analyzing predictive validity, higher AUC results indicate greater ability to predict an outcome. In this study, the discriminative power of AUC was defined according to the traditional academic point system: 90 to 100 (excellent), 80 to 90 (good), 70 to 80 (weak), 60 to 70 (poor), and 60 or below (failure) [40]. This classification has been used in previous studies validating nutritional screening instruments [41,42].

Considering the number and heterogeneity of the studies included in this review, meta-analysis of the prevalence of nutritional risk or malnutrition was not possible.

\section{Results}

The initial database search retrieved 101 records; 13 duplicate studies were removed. Of the 88 remaining articles, which were analyzed by reading the title and abstract, 5 were selected for full-text review. Of these, four studies [43-46], all conducted in China, met the criteria for inclusion in the study: two retrospective cohort studies [43,46], a cross-sectional study [44], and a case series study [45]. Figure 1 shows the study selection flowchart.

\subsection{Methodological Quality of Studies}

The studies evaluated according to the Newcastle-Ottawa scale showed good methodological quality, with total scores of seven stars. The case series study also showed good methodological quality. Of the five questions applicable to this study, four were scored. Table 1 presents the assessment of methodological quality according to study type.

The studies' quality with respect to the nutritional screening instruments employed was evaluated according to the QUADAS criteria. With respect to selection of participants, three studies [44-46] were at high risk of bias, as they did not perform random or consecutive sampling; one was at low risk of bias [43]. Additionally, the study by Yuan et al. [45] did not report data on the nutritional risk of two patients. 

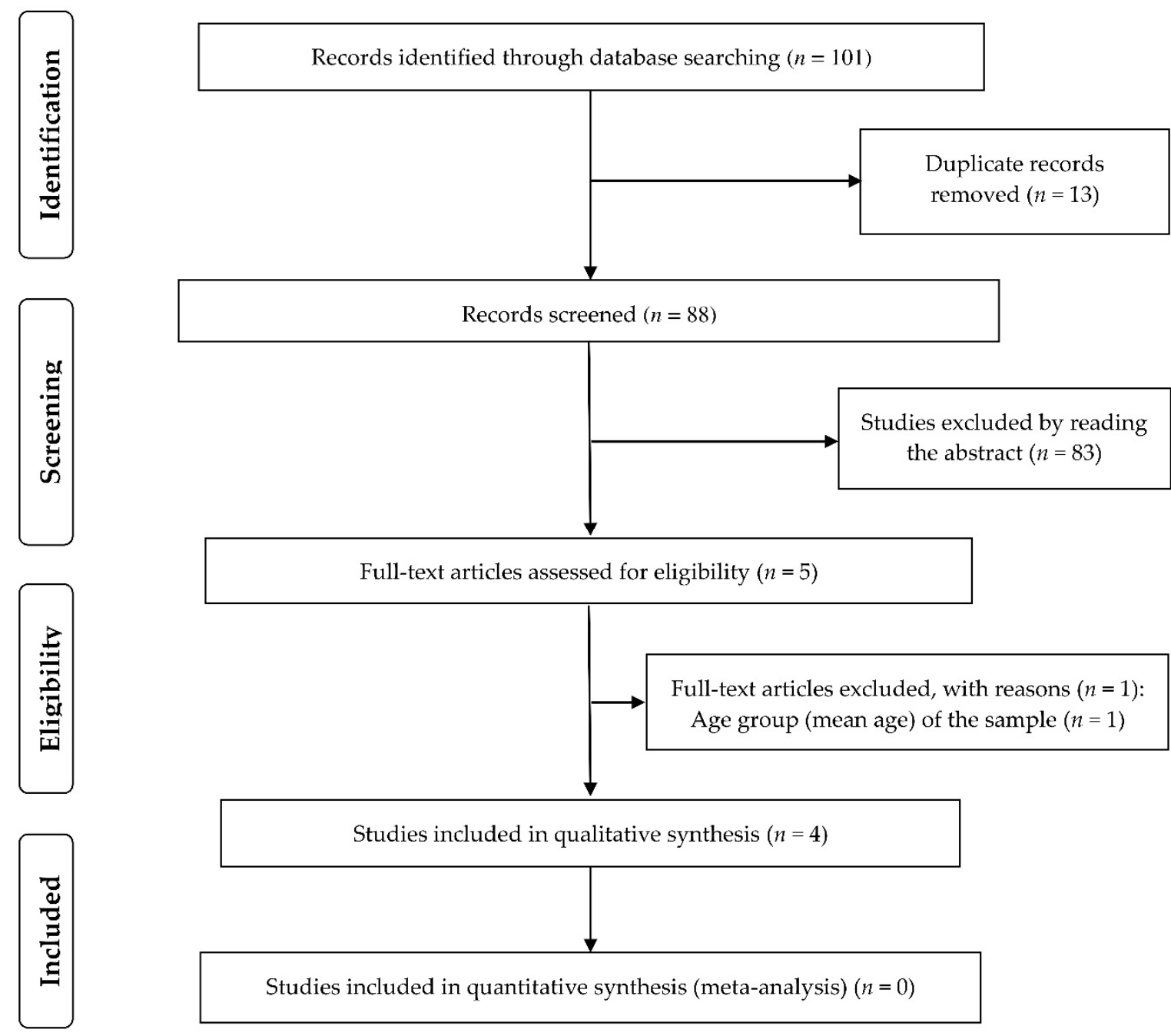

Figure 1. The preferred reporting items for systematic reviews and meta-analyses (PRISMA) flow chart for selection of studies.

Low risk of bias was observed in all the studies with respect to evaluation of the nutritional screening results (index test domain) [43-46], as they defined a cut-off point for the diagnosis of nutritional risk. Two studies compared between the diagnosis of nutritional risk and patients' body mass index (BMI) [44-46], but it was clear that this did not interfere in the diagnosis of patients' nutritional risk.

Two studies [44-46] compared diagnoses of nutritional risk to other nutritional screening tools as well as BMI. In these studies, a low risk of bias was identified with respect to the reference standards used and for the sequence and timing of the comparisons. Although BMI may not be one of the best indicators of nutritional risk when used alone, the study authors adequately addressed the limitations of using BMI to identify nutritional risk or malnutrition, as well as the limitations regarding BMI's predictive validity. Table 2 presents the evaluation of the studies' quality with respect to the instruments used. 
Table 1. Methodological quality of included studies $(n=4)$.

\begin{tabular}{|c|c|c|c|c|c|c|c|c|c|}
\hline \multicolumn{10}{|c|}{ Cohort-Newcastle-Ottawa Scale } \\
\hline & \multicolumn{4}{|c|}{ Selection } & \multicolumn{2}{|c|}{ Comparability } & \multicolumn{3}{|c|}{ Outcome } \\
\hline Quality criteria & $\begin{array}{l}\text { 1. Representativeness } \\
\text { of the exposed cohort }\end{array}$ & $\begin{array}{l}\text { 2. Selection of } \\
\text { the } \\
\text { non-exposed } \\
\text { cohort }\end{array}$ & $\begin{array}{c}3 . \\
\text { Ascertainment } \\
\text { of exposure }\end{array}$ & $\begin{array}{c}4 . \\
\text { Demonstration } \\
\text { that outcome of } \\
\text { interest was not } \\
\text { present at start } \\
\text { of study }\end{array}$ & \multicolumn{2}{|c|}{$\begin{array}{l}\text { 1. Comparability of cohorts on the } \\
\text { basis of the design or analysis }\end{array}$} & $\begin{array}{l}\text { 1. Assessment } \\
\text { of outcome }\end{array}$ & $\begin{array}{l}\text { 2. Was } \\
\text { follow-up long } \\
\text { enough for } \\
\text { outcomes to } \\
\text { occur? }\end{array}$ & $\begin{array}{l}\text { 3. Adequacy of } \\
\text { follow up of cohorts }\end{array}$ \\
\hline $\begin{array}{c}\text { Liu et al., } 2020 \\
{[46]}\end{array}$ & * & \multicolumn{3}{|c|}{ * } & \multicolumn{2}{|c|}{ ** } & * & * & * \\
\hline $\begin{array}{l}\text { Zhang et al., } \\
2020[43]\end{array}$ & * & \multicolumn{3}{|c|}{ * } & \multicolumn{2}{|c|}{ ** } & * & * & * \\
\hline \multicolumn{10}{|c|}{ Cross-sectional-Newcastle-Ottawa Scale } \\
\hline & \multicolumn{4}{|c|}{ Selection } & \multicolumn{2}{|c|}{ Comparability } & \multicolumn{3}{|c|}{ Outcome } \\
\hline Quality criteria & $\begin{array}{l}\text { 1. Representativeness } \\
\text { of the sample }\end{array}$ & 2. Sample size & $\begin{array}{c}3 . \\
\text { Ascertainment } \\
\text { of exposure }\end{array}$ & $\begin{array}{l}4 . \\
\text { Non-respondents }\end{array}$ & $\begin{array}{l}\text { 1. The subjects i } \\
\text { groups are com } \\
\text { the study de } \\
\text { Confounding fa }\end{array}$ & $\begin{array}{l}\text { different outcome } \\
\text { arable, based on } \\
\text { zn or analysis. } \\
\text { rs are controlled. }\end{array}$ & \multicolumn{2}{|c|}{ 1. Assessment of outcome } & 2. Statistical test \\
\hline $\begin{array}{c}\text { Li et al., } 2020 \\
{[44]}\end{array}$ & * & & * & & \multicolumn{2}{|c|}{$* *$} & \multicolumn{2}{|c|}{ ** } & * \\
\hline \multicolumn{10}{|c|}{ Case series-Murad et al. (2018) } \\
\hline & Selection & \multicolumn{2}{|c|}{ Ascertainment } & \multicolumn{5}{|c|}{ Causality } & Reporting \\
\hline Quality criteria & $\begin{array}{l}\text { 1. Does the patient (s) } \\
\text { represent (s) the whole } \\
\text { experience of the } \\
\text { investigator (center), } \\
\text { or is the selection } \\
\text { method unclear to the } \\
\text { extent that other } \\
\text { patients with similar } \\
\text { presentation may not } \\
\text { have been reported? }\end{array}$ & $\begin{array}{l}\text { 2. Was the } \\
\text { exposure } \\
\text { adequately } \\
\text { ascertained? }\end{array}$ & $\begin{array}{l}\text { 3. Was the } \\
\text { outcome } \\
\text { adequately } \\
\text { ascertained? }\end{array}$ & $\begin{array}{l}\text { 4. Were other } \\
\text { alternative } \\
\text { causes that may } \\
\text { explain the } \\
\text { observation } \\
\text { ruled out? }\end{array}$ & $\begin{array}{l}\text { 5. Was there a } \\
\text { challenge/ } \\
\text { rechallenge } \\
\text { phenomenon? }\end{array}$ & $\begin{array}{l}\text { 6. Was there a } \\
\text { dose-response } \\
\text { effect? }\end{array}$ & \multicolumn{2}{|c|}{$\begin{array}{l}\text { 7. Was follow-up long enough for } \\
\text { outcomes to occur? }\end{array}$} & $\begin{array}{l}\text { 8. Is the case (s) } \\
\text { described with } \\
\text { sufficient details to } \\
\text { allow other } \\
\text { investigators to } \\
\text { replicate the } \\
\text { research or to allow } \\
\text { practitioners make } \\
\text { inferences related to } \\
\text { their own practice? }\end{array}$ \\
\hline $\begin{array}{c}\text { Yuan et al., } 2020 \\
{[45]}\end{array}$ & & * & * & NA & NA & NA & \multicolumn{2}{|c|}{ * } & * \\
\hline
\end{tabular}

Notes: for case series, items 4, 5 and 6 are mostly relevant to cases of adverse drug events; ${ }^{*}$, one star; ${ }^{* *}$, two stars. Abbreviations: NA, Not Applicable. 
Table 2. Methodological quality evaluation of each study included in the systematic review according to Quality Assessment of Diagnostic Accuracy Studies (QUADAS; $n=4$ ).

\begin{tabular}{|c|c|c|c|c|c|c|}
\hline \multicolumn{2}{|c|}{ Domain } & Item & Liu et al., 2020 [46] & Li et al., 2020 [44] & Yuan et al., 2020 [45] & Zhang et al., 2020 \\
\hline \multirow{5}{*}{ Patient Selection } & \multirow{3}{*}{$\begin{array}{l}\text { Signaling questions } \\
\text { (yes/no/unclear) }\end{array}$} & \multirow{3}{*}{$\begin{array}{l}\text { Was a consecutive or random } \\
\text { sample of patients enrolled? } \\
\text { Was a case-control design avoided? } \\
\text { Did the study avoid inappropriate } \\
\text { exclusions? }\end{array}$} & No & No & No & Yes \\
\hline & & & Yes & Yes & Yes & Yes \\
\hline & & & Yes & Yes & No & Yes \\
\hline & $\begin{array}{c}\text { Risk of bias: } \\
\text { High/low/unclear }\end{array}$ & $\begin{array}{l}\text { Could the selection of patients } \\
\text { have introduced bias? }\end{array}$ & High & High & High & Low \\
\hline & $\begin{array}{l}\text { Concerns regarding } \\
\text { applicability: } \\
\text { High/low/unclear }\end{array}$ & $\begin{array}{l}\text { Are there concerns that the } \\
\text { included patients do not match the } \\
\text { review question? }\end{array}$ & Low & Low & Low & Low \\
\hline \multirow{4}{*}{ Index Test } & \multirow[t]{2}{*}{$\begin{array}{l}\text { Signaling questions } \\
\text { (yes/no/unclear) }\end{array}$} & $\begin{array}{l}\text { Were the index test results } \\
\text { interpreted without knowledge of } \\
\text { the results of the reference } \\
\text { standard? }\end{array}$ & Unclear & - & - & - \\
\hline & & $\begin{array}{l}\text { If a threshold was used, was it } \\
\text { pre-specified? }\end{array}$ & Yes & Yes & Yes & Yes \\
\hline & $\begin{array}{l}\text { Risk of bias: } \\
\text { High/low/unclear }\end{array}$ & $\begin{array}{l}\text { Could the conduct or } \\
\text { interpretation of the index test } \\
\text { have introduced bias? }\end{array}$ & Low & Low & Low & Low \\
\hline & $\begin{array}{l}\text { Concerns regarding } \\
\text { applicability: } \\
\text { High/low/unclear }\end{array}$ & $\begin{array}{l}\text { Are there concerns that the index } \\
\text { test, its conduct, or interpretation } \\
\text { differ from the review question? }\end{array}$ & Low & Low & Low & Low \\
\hline \multirow{4}{*}{ Reference Standard } & \multirow[t]{2}{*}{$\begin{array}{l}\text { Signaling questions } \\
\text { (yes/no/unclear) }\end{array}$} & $\begin{array}{l}\text { Is the reference standard likely to } \\
\text { correctly classify the target } \\
\text { condition? }\end{array}$ & Yes & Yes & - & - \\
\hline & & $\begin{array}{l}\text { Were the reference standard results } \\
\text { interpreted without knowledge of } \\
\text { the results of the index test? }\end{array}$ & Unclear & Unclear & - & - \\
\hline & $\begin{array}{l}\text { Risk of bias: } \\
\text { High/low/unclear }\end{array}$ & $\begin{array}{l}\text { Could the reference standard, its } \\
\text { conduct, or its interpretation have } \\
\text { introduced bias? }\end{array}$ & Low & Low & - & - \\
\hline & $\begin{array}{l}\text { Concerns regarding } \\
\text { applicability: } \\
\text { High/low/unclear }\end{array}$ & $\begin{array}{l}\text { Are there concerns that the target } \\
\text { condition as defined by the } \\
\text { reference standard does not match } \\
\text { the review question? }\end{array}$ & Low & Low & - & - \\
\hline
\end{tabular}


Table 2. Cont.

\begin{tabular}{|c|c|c|c|c|c|c|}
\hline & & Item & Liu et al., 2020 [46] & Li et al., 2020 [44] & Yuan et al., 2020 [45] & Zhang et al., 2020 [43] \\
\hline \multirow{5}{*}{ Flow and Timing } & \multirow{4}{*}{$\begin{array}{l}\text { Signaling questions } \\
\text { (yes/no/unclear) }\end{array}$} & $\begin{array}{l}\text { Was there an appropriate interval } \\
\text { between index test (s) and } \\
\text { reference standard? }\end{array}$ & Yes & Yes & - & - \\
\hline & & $\begin{array}{l}\text { Did all patients receive a } \\
\text { reference standard? }\end{array}$ & Yes & Yes & - & - \\
\hline & & $\begin{array}{l}\text { Did all patients receive the same } \\
\text { reference standard? }\end{array}$ & Yes & Yes & - & - \\
\hline & & $\begin{array}{l}\text { Were all patients included in } \\
\text { the analysis? }\end{array}$ & Yes & Yes & - & - \\
\hline & $\begin{array}{l}\text { Risk of bias: } \\
\text { High/low/unclear }\end{array}$ & $\begin{array}{l}\text { Could the patient flow have } \\
\text { introduced bias? }\end{array}$ & Low & Low & - & - \\
\hline
\end{tabular}




\subsection{Participants' Characteristics}

The number of participants in each study ranged from six [45] to 182 [44], and ages ranged from $65[44,46]$ to 87 years [46]. Three studies included more women than men [44-46]. Table 3 illustrates the characteristics of the participants and instruments used in each study.

Table 3. Characteristics of participants included in the studies $(n=4)$.

\begin{tabular}{|c|c|c|c|c|c|c|c|}
\hline Author & Country & Design & $n$ & $\begin{array}{l}\text { Age Group } \\
\text { (Years) }\end{array}$ & Sex & $\begin{array}{l}\text { Nutritional } \\
\text { Screening Tool }\end{array}$ & Nutritional Risk \\
\hline $\begin{array}{l}\text { Liu et al., } \\
2020 \text { [46] }\end{array}$ & China & $\begin{array}{l}\text { Retrospective } \\
\text { cohort }\end{array}$ & 141 & 65 to 87 & $\begin{array}{c}\text { Women: } 73 . \\
\text { Men: } 68\end{array}$ & $\begin{array}{c}\text { NRS-2002-NR: score } \\
\geq 3 \text { (out of a } \\
\text { maximum of } 6 \text { ); } \\
\text { MNA-sf-NR: score }< \\
12 \text { (out of a } \\
\text { maximum of } 14 \text { ); } \\
\text { MUST-NR: score } \geq 2 \\
\text { (out of a maximum } \\
\text { of } 6 \text { ); } \\
\text { NRI-SNR: score }< \\
83.5 \text { and no } \\
\text { NR }>100 .\end{array}$ & $\begin{array}{c}\text { NRS-2002: } 120 \\
\text { (85.1\%); } \\
\text { MNA-sf: } 109 \\
(77.3 \%) ; \\
\text { MUST: } 58(41.1 \%) ; \\
\text { NRI: } 101(60.4 \%) .\end{array}$ \\
\hline $\begin{array}{l}\text { Li et al., } \\
2020 \text { [44] }\end{array}$ & China & Cross-sectional & 182 & $\begin{array}{c}\text { Average age } \\
\text { of } 68.5 \text { years } \\
\text { old }\end{array}$ & $\begin{array}{l}\text { Women: } \\
\text { 117. Man: } \\
65 .\end{array}$ & $\begin{array}{c}\text { MNA: } \\
\text { No NR/malnutrition } \\
\geq 24 ; \\
\text { risk of malnutrition: } \\
17-23.5 ; \\
\text { malnutrition }<17\end{array}$ & $\begin{array}{c}\text { No nutritional } \\
\text { risk/malnutrition: } 36 \\
(19.8 \%) ; \\
\text { risk of malnutrition: } \\
50(27.5 \%) ; \\
\text { malnutrition: } 96 \\
(52.7 \%) .\end{array}$ \\
\hline $\begin{array}{l}\text { Yuan et al., } \\
2020 \text { [45] }\end{array}$ & China & Case series & $6^{1}$ & 65 to 71 & $\begin{array}{l}\text { Women: } 4 . \\
\text { Man: } 2 .\end{array}$ & $\begin{array}{c}\text { GNRI: } \\
\text { High NR: score < } \\
\text { 82-cut-off point } \\
\text { used to diagnose } \\
\text { nutritional risk in } \\
\text { the study; } \\
\text { moderate NR: score } \\
\text { from } 82 \text { to }<92 ; \\
\text { low NR: score from } \\
92 \text { to } \leq 98 ; \\
\text { no risk: score }>98 \text {. }\end{array}$ & $4(100 \%)$ \\
\hline
\end{tabular}

Abbreviations: GNRI, Geriatric Nutritional Risk Index; MNA, Mini Nutritional Assessment; MNA-sf, Mini Nutritional Assessment-short form; MUST, Malnutrition Universal Screening Tool; NRI, Nutritional Risk Index; NRS-2002, Nutritional Risk Screening tool 2002; NUTRIC score, modified Nutrition Risk in the Critically ill (mNUTRIC) score; NR, nutritional risk; SNR, severe nutritional risk. ${ }^{1}$ For four participants, data on nutritional risk were provided.

\subsection{COVID-19 Diagnosis Method}

Li et al. [44] diagnosed COVID-19 according to a positive reverse-transcriptase polymerase chain reaction (RT-PCR) test for SARS-CoV-2. Liu et al. [46] diagnosed and classified COVID-19 using a combination of several criteria, including history of epidemiological exposure; characteristic symptoms of COVID-19, such as fever, cough, and gastrointestinal symptoms; laboratory tests with changes in lymphocyte count and number of white blood cells; changes in pulmonary imaging tests; and a positive RT-PCR test result for SARS-CoV-2 using respiratory or blood specimens.

Yuan et al. [45] used only RT-PCR test results to diagnose COVID-19 in two patients; PCR-RT test results and history of epidemiological exposure in two other patients; and a combination of clinical, epidemiological, and laboratory test information for the final two patients.

Zhang et al. [43] diagnosed and clinically classified COVID-19 according to the Guidance for Coronavirus Disease 2019 (6th edition) published by the National Health Commission of China, which includes criteria related to the RT-PCR test and the characteristic symptoms of COVID-19. 


\subsection{Nutritional Screening Instruments Used to Identify Nutritional Risk}

The studies used various nutritional screening tools to identify nutritional risk in older people with COVID-19. Liu et al. [46] used four different instruments: the NRS-2002, MNA-sf, MUST, and NRI. Cut-off scores for diagnosis of nutritional risk were $\geq 3$ points for the NRS-2002 (out of 6) [14], $<12$ for the MNA-sf (out of 14) [11,12], $\geq 2$ for the MUST (out of 6) [15], and <83.5 for the NRI (severe risk of malnutrition; a score of $>100$ indicates no risk) [16].

Li et al. [44] used the full version of the MNA to assess the nutritional risk, with three classifications: no risk of malnutrition ( $\geq 24$ points), risk of malnutrition (17-23.5 points), and malnutrition ( $<17$ points).Yuan et al. [45] used the GNRI, with four categories: high risk, the cut-off point used to diagnose nutritional risk (<82 points), moderate risk (82-91 points), low risk (92-98 points), and no risk ( $>98$ points). Zhang et al. [43] used mNUTRIC scores with two categories: high nutritional risk ( $\geq 5$ points) and low nutritional risk ( $<5$ points). Table 4 presents the parameters for each instrument.

Table 4. Parameters of nutritional screening tools used in the included studies.

\begin{tabular}{|c|c|c|c|}
\hline Tool & Criteria & Score & Applications \\
\hline GNRI & $\begin{array}{l}\text { GNRI }=(14.89 \times \text { albumin }(\mathrm{g} / \mathrm{dL}))+(41.7 \\
\quad \times(\text { body weight/ideal body weight }))\end{array}$ & $\begin{array}{l}\text { Low NR } 92-\leq 98 . \text { Moderate } \\
\text { NR: } 82-<92 . \text { High NR }<82 \text {. }\end{array}$ & $\begin{array}{l}\text { Recommended settings: } \\
\text { hospital. }\end{array}$ \\
\hline NRS-2002 & $\begin{array}{l}\text { Two domains: disease severity score and } \\
\text { nutritional score. } \\
\text { Disease severity score domain: patients } \\
\text { with diabetes, cancer, COPD (1 point); } \\
\text { patients with severe pneumonia } \\
\text { (2 points); intensive care patients } \\
\text { (APACHE > 10) ( } 3 \text { points). } \\
\text { Nutritional score domain: Weight loss } \\
\text { greater than } 5 \% \text { in the last three months } \\
\text { or food intake between } 50 \% \text { and } 75 \% \text { of } \\
\text { nutritional needs ( } 1 \text { point); weight loss } \\
\text { greater than } 5 \% \text { in the last two months, } \\
\text { food intake between } 25 \% \text { and } 60 \% \text { of } \\
\text { nutritional needs, or BMI } 18.5-20.5 \text { with } \\
\text { impaired general health ( } 2 \text { points); } \\
\text { weight loss greater than } 5 \% \text { in one } \\
\text { month, }>15 \% \text { in three months, or food } \\
\text { intake between } 0 \% \text { and } 25 \% \text { of } \\
\text { nutritional needs ( } 3 \text { points). } \\
\text { Score adjusted for age: if } \geq 70 \text { years, one } \\
\text { additional point. }\end{array}$ & NR: score $\geq 3$ & $\begin{array}{l}\text { Recommended settings: } \\
\text { hospital, home care, and } \\
\text { community. }\end{array}$ \\
\hline
\end{tabular}


Table 4. Cont.

\begin{tabular}{|c|c|c|c|}
\hline Tool & Criteria & Score & Applications \\
\hline NUTRIC score & $\begin{array}{l}\text { Six domains: age, APACHE, SOFA, } \\
\text { number of comorbidities, days from } \\
\text { hospital to ICU admission, and IL-6. } \\
\text { Age: }<50(0) ; 50-74(1) ; \geq 75(2) . \\
\text { APACHE II: }<15(0) ; 15-19(1) ; 20-28(2) ; \\
\quad \geq 28(3) . \\
\text { SOFA: }<6(0) ; 6-9(1) ; \geq 10(2) . \\
\text { Number of comorbidities: } 0-1(0) ; \geq 2(1) . \\
\text { Days from hospital to ICU admission: } \\
0-<1(0) ; \geq(1) \\
\text { IL-6: } 0-<400(0) ; \geq 400(1) .\end{array}$ & $\begin{array}{l}\text { Score with IL-6: Low NR: } \\
\text { 0-5. High NR: 6-10. } \\
\text { Score without IL-6: Low NR: } \\
\text { 0-4. High NR: 5-9. }\end{array}$ & $\begin{array}{l}\text { Recommended settings: } \\
\text { critically ill patients (ICU). }\end{array}$ \\
\hline MNA-sf & 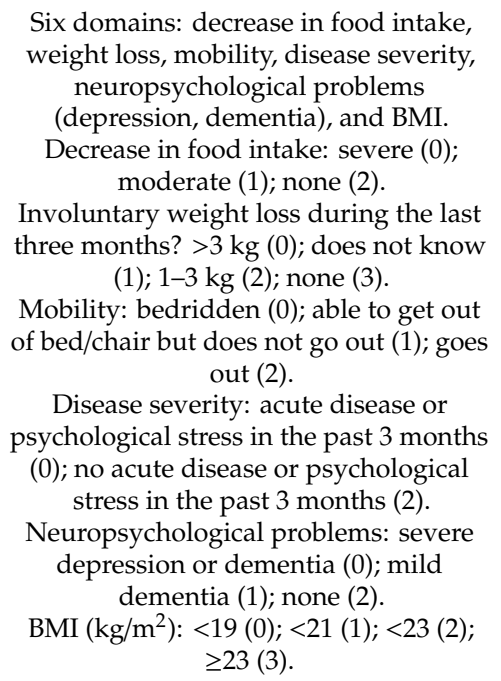 & $\begin{array}{l}\text { Normal: } 12-14 . \\
\text { Risk of malnutrition: } 8-11 \text {. } \\
\text { Malnutrition: } 0-7 \text {. }\end{array}$ & $\begin{array}{l}\text { Recommended settings: } \\
\text { hospital, home care, and } \\
\text { community. }\end{array}$ \\
\hline
\end{tabular}

Abbreviations: APACHE, Acute Physiology and Chronic Health Evaluation; BMI, body mass index; COPD, chronic obstructive pulmonary disease; GNRI, Geriatric Nutritional Risk Index; ICU, intensive care unit; IL-6, Interleukin-6; MNA, Mini Nutritional Assessment; MNA-sf, Mini Nutritional Assessment-short form; MUST, Malnutrition Universal Screening Tool; NRI, Nutritional Risk Index; NRS-2002, Nutritional Risk Screening tool 2002; NUTRIC score, modified Nutrition Risk in the Critically ill (mNUTRIC) score; NR, nutritional risk; SOFA, Sequential Organ Failure Assessment score.

\subsection{Nutritional Risk in Older Adults with COVID-19}

Based on the various instruments applied, the prevalence rates of nutritional risk in Liu et al.'s study [46] were $85.1 \%$ (NRS-2002), 77.3\% (MNA-sf), 60.4\% (NRI), and 41.1\% (MUST) [46]. Li et al. found that 50 patients $(27.5 \%)$ were at risk of malnutrition and $96(52.7 \%)$ were malnourished [44]. Based on mNUTRIC scores, Zhang et al. found that $61 \%$ of patients had a high nutritional risk [43]. All four participants with reported GNRI evaluation data were classified by Yuan et al. as at high nutritional risk [45]. 


\subsection{Association between Comorbidities and Nutritional Risk}

Li et al. found that diabetes mellitus was associated with higher nutritional risk and malnutrition (odds ratio (OR): 2.12, 95\% CI: 1.92-3.21) [44]. Liu et al. found no significant associations between arterial hypertension, vascular and cerebrovascular diseases, and nutritional risk [46]. Zhang et al. found no significant associations between nutritional risk and hypertension, diabetes, cardiovascular disease, malignancy, chronic obstructive pulmonary disease, chronic kidney disease, liver cirrhosis, or immunopathy [43].

\subsection{Sensitivity, Specificity, and Criterion Validity of Nutritional Screening Instruments}

Liu et al. [46] compared diagnoses of nutritional risk between the different instruments and with cut-off points of BMI. Compared to the cut-off points for BMI, all the instruments (NRS-2002, MNA-sf, MUST, and NRI) demonstrated 100\% sensitivity. Between the instruments, only the MUST showed a sensitivity of less than 50\% compared to the NRS-2002.

Only the MUST showed better specificity compared to BMI $(62 \%)$. Between the instruments, good specificity was identified for the MUST vs. the NRS-2002 (95\%), the MUST vs. the NRI (88\%), the MNA-sf vs. the NRS-2002 (86\%), and the MNA-sf vs. the MUST (97\%).

The NRS-2002 was the only instrument to present an NPV above 80\% compared to BMI, the MUST, and the NRI. All instruments had a PPV below 13\% when compared to BMI. The GNRI demonstrated a PPV of $25 \%$.

The MNA showed weak criterion validity, demonstrating a significant correlation with BMI, calf circumference, albumin, and TLC but no correlation with tricipital skinfold thickness and arm circumference. The MUST, NRS-2002, MNA-sf, and NRI all showed poor criterion validity compared to BMI. The GNRI demonstrated poor construct validity when compared to TLC. mNUTRIC score demonstrated poor construct validity, having a significant correlation with TLC and creatinine but no correlation with albumin and pre-albumin levels. Table 5 reports the diagnostic performance of the nutritional screening and assessment instruments included in this review.

\subsection{Predictive Validity of Screening and Nutritional Assessment Instruments}

In the study by Liu et al. [46], patients with nutritional risk according to the NRS-2002, MNA-sf, and NRI exhibited longer hospitalization, worse disease, worse appetite, and greater weight change than patients without nutritional risk. Diagnosis of nutritional risk according to the MUST predicted worse appetite and weight change, but not of worsening disease or prolonged hospitalization.

Zhang et al. [43] found that mNUTRIC score predicted complications in the ICU such as acute respiratory distress syndrome (ARDS), shock, acute myocardial injury, secondary infection, and death in the ICU after 28 days of hospitalization, but did not predict acute liver dysfunction, embolization/thrombosis, acute kidney injury, or pneumothorax.

The NRS-2002 had poor predictive validity for patients' length of hospital stay and poor validity for hospital expenses, decreased appetite, and weight loss of more than $2.6 \mathrm{~kg}$. The MNA-sf had good predictive validity for changes in appetite and weight, but weak predictive validity for length of hospital stay, and failure for hospital expenses. The MUST had good predictive validity for weight change and poor predictive validity for appetite change. The NRI demonstrated poor predictive validity for all analyzed outcomes. mNUTRIC scores showed good predictive validity for complications in the ICU such as ARDS, shock, acute myocardial injury, secondary infection, and ICU mortality after 28 days of hospitalization. Table 6 presents the analysis of the predictive validity of the nutritional screening instruments included in this review. 
Table 5. Diagnostic performance of Nutritional Screening Tools identifying older adults with COVID-19 at nutritional risk or with malnutrition.

\begin{tabular}{|c|c|c|c|c|c|c|c|c|c|c|c|}
\hline Author & Screening Tool & Reference Standard & TP & FP & FN & TN & $\begin{array}{l}\text { Sensitivity } \\
(95 \% \mathrm{CI})\end{array}$ & $\begin{array}{l}\text { Specificity } \\
\text { (95\% CI) }\end{array}$ & $\begin{array}{l}\mathrm{PPV} \\
(\%)\end{array}$ & $\begin{array}{l}\text { NPV } \\
(\%)\end{array}$ & Other Analysis \\
\hline Liu et al., 2020 [46] & NRS-2002 & BMI & 7 & 113 & 0 & 21 & 100 (59 to 100 ) & 16 (10 to 23) & 5.8 & 100 & - \\
\hline Liu et al., 2020 [46] & NRS-2002 & MUST & 57 & 63 & 1 & 20 & 98 (91 to 100 ) & $24(15$ to 35$)$ & 47.5 & 95.2 & - \\
\hline Liu et al., 2020 [46] & NRS-2002 & MNA-sf & 102 & 18 & 7 & 14 & 94 (87 to 97$)$ & 44 (26 to 62$)$ & 85.0 & 66.7 & - \\
\hline Liu et al., 2020 [46] & NRS-2002 & NRI & 98 & 22 & 3 & 18 & 97 (92 to 99 ) & 45 (29 to 62$)$ & 81.7 & 85.7 & - \\
\hline Liu et al., 2020 [46] & MUST & BMI & 7 & 51 & 0 & 83 & 100 (59 to 100$)$ & 62 (53 to 70 ) & 12.1 & 100 & - \\
\hline Liu et al., 2020 [46] & MUST & NRS-2002 & 57 & 1 & 63 & 20 & 47 (38 to 57$)$ & 95 (76 to 100$)$ & 98.3 & 24.1 & - \\
\hline Liu et al., 2020 [46] & MUST & MNA-sf & 57 & 52 & 1 & 31 & 98 (91 to 100 ) & 37 (27 to 49$)$ & 52.3 & 96.9 & - \\
\hline Liu et al., 2020 [46] & MUST & NRI & 53 & 5 & 48 & 35 & 52 (42 to 63$)$ & 88 (73 to 96 ) & 91.4 & 42.2 & - \\
\hline Liu et al., 2020 [46] & MNA-sf & BMI & 7 & 102 & 0 & 32 & 100 (59 to 100$)$ & 24 (17 to 32$)$ & 6.4 & 100 & - \\
\hline Liu et al., 2020 [46] & MNA-sf & NRI & 86 & 23 & 15 & 17 & 85 (77 to 91 ) & $42(27$ to 59$)$ & 78.9 & 53.1 & - \\
\hline Liu et al., 2020 [46] & MNA-sf & NRS-2002 & 102 & 3 & 22 & 18 & 82 (74 to 99 ) & 86 (64 to 97$)$ & 97.1 & 45.0 & - \\
\hline Liu et al., 2020 [46] & MNA-sf & MUST & 57 & 1 & 52 & 31 & 52 (43 to 62 ) & 97 (84 to 100$)$ & 98.3 & 37.4 & - \\
\hline Liu et al., 2020 [46] & NRI & BMI & 7 & 94 & 0 & 40 & 100 (59 to 100$)$ & $30(22$ to 38$)$ & 6.9 & 100 & - \\
\hline Liu et al., 2020 [46] & NRI & MNA-sf & 86 & 15 & 23 & 17 & 79 (70 to 86$)$ & 53 (35 to 71$)$ & 85.2 & 42.5 & - \\
\hline Liu et al., 2020 [46] & NRI & NRS-2002 & 98 & 3 & 22 & 18 & 82 (74 to 88$)$ & 86 (64 to 97$)$ & 97.0 & 45.0 & - \\
\hline Liu et al., 2020 [46] & NRI & MUST & 53 & 48 & 35 & 5 & 60 (49 to 61 ) & $9(3$ to 21$)$ & 52.5 & 12.5 & - \\
\hline Li et al., 2020 [44] & MNA & BMI & - & - & - & - & - & - & - & - & $\begin{array}{c}\text { BMI }\left(\mathrm{kg} / \mathrm{m}^{2}\right)-\text { no malnutrition: } 25.6 \pm 3.0 ; \text { risk of } \\
\text { malnutrition: } 23.3 \pm 3.4 \mathrm{~kg} / \mathrm{m}^{2} ; \text { malnutrition: } 21.1 \pm 3.6 \\
\mathrm{~kg} / \mathrm{m}^{2} . \text { For } X^{2} \text { value: } 4.106, p=0.035 .\end{array}$ \\
\hline Li et al., 2020 [44] & MNA & $\begin{array}{l}\text { Calf circumference } \\
(\mathrm{cm})\end{array}$ & - & - & - & - & - & - & - & - & $\begin{array}{c}\text { Calf circumference }(\mathrm{cm})-\text { no malnutrition: } 33.4 \pm 5.6 \text {; } \\
\text { risk of malnutrition: } 31.2 \pm 4.8 ; \text { malnutrition: } 28.7 \pm \\
5.7, \text { F or } X^{2} \text { value: } 2.518, p=0.047 .\end{array}$ \\
\hline Li et al., 2020 [44] & MNA & Albumin $(\mathrm{g} / \mathrm{L})$ & - & - & - & - & - & - & - & - & $\begin{array}{l}\text { Albumin }(\mathrm{g} / \mathrm{L}) \text {-no malnutrition: } 38.5 \pm 4.2 \text {; risk of } \\
\text { malnutrition: } 30.1 \pm 6.4 \text {; malnutrition: } 25.7 \pm 5.3, \mathrm{~F} \text { or } \\
\mathrm{X}^{2} \text { value: } 10.217, p<0.001 .\end{array}$ \\
\hline Li et al., 2020 [44] & MNA & TLC & - & - & - & - & - & - & - & - & $\begin{array}{c}\text { TLC-no malnutrition: } 1.7 \pm 0.52 \text {; risk of malnutrition: } \\
1.2 \pm 0.43 \text {, malnutrition: } 0.9 \pm 0.38, \mathrm{~F} \text { or } \mathrm{X}^{2} \text { value: } \\
11.237, p<0.001 .\end{array}$ \\
\hline Li et al., 2020 [44] & MNA & TSFT (mm) & - & - & - & - & - & - & - & - & $\begin{array}{c}\text { TSFT }(\mathrm{mm})-\text { no malnutrition: } 16.8 \pm 7.2 \text {; risk of } \\
\text { malnutrition: } 15.7 \pm 6.9 ; \text { malnutrition: } 14.9 \pm 7.3, \mathrm{~F} \text { or } \\
\mathrm{X}^{2} \text { value: } 1.632, p=0.126 .\end{array}$ \\
\hline Li et al., 2020 [44] & MNA & $\operatorname{MAC}(\mathrm{cm})$ & - & - & - & - & - & - & - & - & $\begin{array}{c}\mathrm{MAC}(\mathrm{cm})-\text { no malnutrition: } 28.7 \pm 2.8 \text {; risk of } \\
\text { malnutrition: } 27.6 \pm 3.3 ; \text { malnutrition: } 26.5 \pm 3.2, \mathrm{~F} \text { or } \\
\mathrm{X}^{2} \text { value: } 2.679, p=0.379 .\end{array}$ \\
\hline Yuan et al., 2020 [45] & GNRI & TLC & - & - & - & - & - & - & - & - & $\begin{array}{l}\text { Of the four patients at nutritional risk, one had low } \\
\text { TLC levels and three had normal levels. }\end{array}$ \\
\hline Zhang et al., 2020 [43] & NUTRIC score & Albumin $(\mathrm{g} / \mathrm{L})$ & - & - & - & - & - & - & - & - & $\begin{array}{l}\text { High NR group }(n=83): 29 \mathrm{~g} / \mathrm{L}(25-32) \\
\text { Low NR group }(n=53): 30 \mathrm{~g} / \mathrm{L}(28-32), p=0.107 .\end{array}$ \\
\hline Zhang et al., 2020 [43] & NUTRIC score & Prealbumin $(\mathrm{g} / \mathrm{L})$ & - & - & - & - & - & - & - & - & $\begin{array}{l}\text { High NR group }(n=83): 82 \mathrm{~g} / \mathrm{L}(80-122) \\
\text { Low NR group }(n=53): 95(80-128) \mathrm{g} / \mathrm{L}, p=0.281 \text {. }\end{array}$ \\
\hline Zhang et al., 2020 [43] & NUTRIC score & TLC & - & - & - & - & - & - & - & - & $\begin{array}{l}\text { High NR group }(n=83): 0.5 \times 10^{9} / \mathrm{L}(0.3-0.7) \\
\text { Low NR group }(n=53): 0.6 \times 10^{9} / \mathrm{L}(0.4-0.9), p=0.007 .\end{array}$ \\
\hline Zhang et al., 2020 [43] & NUTRIC score & Creatinine $(\mathrm{mmol} / \mathrm{L})$ & - & - & - & - & - & - & - & - & $\begin{array}{l}\text { High NR group }(n=83): 90(65-144) \mathrm{mmol} / \mathrm{L} . \\
\text { Low NR group }(n=53): 67(54-85) \mathrm{mmol} / \mathrm{L}, p<0.001 .\end{array}$ \\
\hline
\end{tabular}

(n) Mini Nutritional Assessment; MNA-sf, Mini Nutritional Assessment-short form; MUST, Malnutrition Universal Screening Tool; NPV, negative predictive value; NR, nutritional risk, NRI, Nutritional Risk Index; NRS-2002, Nutritional Risk Screening tool 2002; NUTRIC, Nutrition Risk in the Critically Ill (NUTRIC) scores; PPV, positive predictive value; TLC, total lymphocyte count; TN, true negative; TP, true positive; TSFT, triceps skin-fold thickness (mm). 
Table 6. Predictive validity of various tools used to evaluate nutritional risk or malnutrition in older adults with COVID-19.

\begin{tabular}{|c|c|c|c|c|c|c|c|}
\hline Author & NST & $\begin{array}{l}\text { Length of Stay } \\
\text { (LOS) }\end{array}$ & Appetite Change & Weight Change & Hospital Expenses & Complications & Mortality \\
\hline Liu et al., 2020 [46] & NRS-2002 & $\begin{array}{c}\text { Nutritional risk } \\
\text { predicted longer } \\
\text { LOS; OR }(95 \% \text { CI): } \\
0.102 \text { (0.042-0.250), } \\
p=0.000 ; \text { AUC for } \\
\text { LOS > 30 days }(95 \% \\
\text { CI): } 0.724 \\
(0.640-0.808), \\
p=0.000 . \\
\text { Rating: Weak. }\end{array}$ & $\begin{array}{c}\text { Nutritional risk } \\
\text { predicted change in } \\
\text { appetite; OR }(95 \% \mathrm{CI}) \\
\text { for no change: } 11.179 \\
(3.881-32.169), \\
p=0.000 ; \text { AUC for } \\
\text { poor appetite }(95 \% \\
\text { CI): } 0.670 \\
(0.586-0.747) \\
p=0.014 . \\
\text { Rating: Poor. }\end{array}$ & $\begin{array}{c}\text { Nutritional risk } \\
\text { predicted weight } \\
\text { change; OR }(95 \% \mathrm{CI}) \text { : } \\
0.128(0.047-0.350), \\
p=0.000 ; \text { AUC for } \\
\text { weight change }>2.6 \\
\mathrm{~kg}(95 \% \mathrm{CI}): 0.613 \\
(0.528-0.694), \\
p=0.000 . \\
\text { Rating: Poor. }\end{array}$ & $\begin{array}{c}\text { Nutritional risk predicted } \\
\text { higher hospital expenses } \\
\text { (CNY); OR (95\% CI): } \\
0.131(0.054-0.313), \\
p=0.000 ; \text { AUC for } \\
\text { hospital expenses }>\text { CNY } \\
56,163(95 \% \text { CI): } 0.667 \\
(0.583-0.744), p=0.000 . \\
\text { Rating: Poor. }\end{array}$ & $\begin{array}{c}\text { Nutritional risk predicted } \\
\text { greater disease severity; } \\
\text { OR }(95 \% \text { CI): } 0.095 \\
(0.031-0.292), p=0.000\end{array}$ & - \\
\hline Liu et al., 2020 [46] & MNA-sf & $\begin{array}{c}\text { Nutritional risk } \\
\text { predicted longer } \\
\text { LOS; OR }(95 \% \text { CI): } \\
0.401 \text { (0.198-0.813), } \\
p=0.011 \text {; AUC for } \\
\text { LOS > 30 days ( } 95 \% \\
\text { CI): } 0.602 \\
(0.304-0.492), \\
p=0.032 . \\
\text { Rating: Poor. }\end{array}$ & $\begin{array}{c}\text { Nutritional risk } \\
\text { predicted change in } \\
\text { appetite; OR }(95 \% \mathrm{CI}) \\
\text { for no change: } 40.731 \\
(13.681-121.389), \\
p=0.000 ; \text { AUC for } \\
\text { poor appetite }(95 \% \\
\text { CI): } 0.868 \\
(0.801-0.919), \\
p=0.000 . \\
\text { Rating: Good. }\end{array}$ & $\begin{array}{c}\text { Nutritional risk } \\
\text { predicted weight } \\
\text { change; OR }(95 \% \text { CI): } \\
0.085 \text { (0.035-0.206), } \\
p=0.000 ; \text { AUC for } \\
\text { weight change }>2.6 \\
\text { kg }(95 \% \text { CI): } 0.895 \\
(0.832-0.940), \\
p=0.000 . \\
\text { Rating: Good. }\end{array}$ & $\begin{array}{c}\text { Nutritional risk predicted } \\
\text { higher hospital expenses } \\
\text { (CNY); OR (95\% CI): } \\
0.436(0.216-0.880), \\
p=0.021 ; \text { AUC for } \\
\text { hospital expenses }>\text { CNY } \\
56,163(95 \% \text { CI): } 0.597 \\
(0.511-0.679), p=0.063 . \\
\text { Rating: Failure. }\end{array}$ & $\begin{array}{c}\text { Nutritional risk predicted } \\
\text { greater disease severity; } \\
\text { OR }(95 \% \text { CI): } 0.632 \\
(0.289-1.382), p=0.250 . \\
\text { Rating: Poor. }\end{array}$ & - \\
\hline Liu et al., 2020 [46] & MUST & $\begin{array}{c}\text { Nutritional risk did } \\
\text { not predict longer } \\
\text { LOS; OR ( } 95 \% \text { CI): } \\
0.722 \text { (0.391-1.334), } \\
p=0.298 ; \\
\text { non-significant AUC } \\
\text { for LOS > 30 days } \\
\text { (95\% CI): } 0.506 \\
(0.421-0.591) \\
p=0.887\end{array}$ & $\begin{array}{c}\text { Nutritional risk } \\
\text { predicted change in } \\
\text { appetite; OR }(95 \% \mathrm{CI}) \\
\text { for no change: } 2.866 \\
(1.449-5.669), \\
p=0.002 ; \text { AUC for } \\
\text { poor appetite }(95 \% \\
\text { CI): } 0.614 \\
(0.528-0.694) \\
p=0.009 \text {. } \\
\text { Rating: Poor. }\end{array}$ & $\begin{array}{c}\text { Nutritional risk } \\
\text { predicted weight } \\
\text { change; OR }(95 \% \mathrm{CI}) \text { : } \\
0.009 \text { (0.003-0.026), } \\
p=0.000 ; \text { AUC for } \\
\text { weight change >2.6 } \\
\mathrm{kg}(95 \% \mathrm{CI}): 0.887 \\
(0.823-0.934), \\
p=0.000 . \\
\text { Rating: Good. }\end{array}$ & $\begin{array}{c}\text { Nutritional risk did not } \\
\text { predict higher hospital } \\
\text { expenses (CNY); OR } \\
(95 \% \text { CI): } 0.599 \\
(0.323-1.109), p=0.103 ; \\
\text { non-significant AUC for } \\
\text { hospital expenses }>\text { CNY } \\
56,163(95 \% \text { CI): } 0.516 \\
(0.430-0.601), p=0.735 .\end{array}$ & $\begin{array}{c}\text { Nutritional risk did not } \\
\text { predict greater disease } \\
\text { severity OR }(95 \% \mathrm{CI}): \\
1.367(0.688-2.718) \\
p=0.372 .\end{array}$ & - \\
\hline
\end{tabular}


Table 6. Cont.

\begin{tabular}{|c|c|c|c|c|c|c|c|}
\hline Author & NST & $\begin{array}{l}\text { Length of Stay } \\
\text { (LOS) }\end{array}$ & Appetite Change & Weight Change & Hospital Expenses & Complications & Mortality \\
\hline Liu et al., 2020 [46] & NRI & $\begin{array}{c}\text { Nutritional risk } \\
\text { predicted longer } \\
\text { LOS; OR }(95 \% \text { CI): } \\
0.261(0.133-0.513), \\
p=0.000 ; \text { AUC for } \\
\text { LOS > 30 days ( } 95 \% \\
\text { CI): } 0.664 \text { ( }-0.579 \text { to } \\
\text { 0.741), } p=0.000 . \\
\text { Rating: Poor. }\end{array}$ & $\begin{array}{c}\text { Nutritional risk } \\
\text { predicted change in } \\
\text { appetite; OR }(95 \% \mathrm{CI}) \\
\text { for no change: } 2.768 \\
\text { (1.363-5.618). } \\
p=0.005 ; \text { AUC for } \\
\text { poor appetite }(95 \% \\
\text { CI): } 0.629 \\
(0.544-0.709), \\
p=0.014 . \\
\text { Rating: Poor. }\end{array}$ & $\begin{array}{c}\text { Nutritional risk } \\
\text { predicted weight } \\
\text { change; OR (95\% CI): } \\
0.182 \text { (0.087-0.378), } \\
p=0.000 ; \text { AUC for } \\
\text { weight change }>2.6 \\
\text { kg (95\% CI): } 0.697 \\
(0.614-0.772), \\
p=0.000 . \\
\text { Rating: Poor. }\end{array}$ & $\begin{array}{c}\text { Nutritional risk predicted } \\
\text { higher hospital expenses } \\
\text { (CNY); OR ( } 95 \% \mathrm{CI}): \\
0.199(0.100-0.397), \\
p=0.000 ; \text { AUC for } \\
\text { hospital expenses }>\text { CNY } \\
56,163(95 \% \text { CI): } 0.621 \\
(0.535-0.701), p=0.019 . \\
\text { Rating: Poor. }\end{array}$ & $\begin{array}{c}\text { Nutritional risk predicted } \\
\text { greater disease severity; } \\
\text { OR (95\% CI): } 0.367 \\
(0.173-0.776), p=0.009\end{array}$ & - \\
\hline $\begin{array}{c}\text { Zhang et al., } 2020 \\
\text { [43] }\end{array}$ & $\begin{array}{c}\text { mNUTRIC } \\
\text { score }\end{array}$ & & & & & $\begin{array}{c}\text { Nutritional risk } \\
\text { correlated with } \\
\text { complications during } \\
\text { ICU stay: ARDS } \\
(p<0.001) \text {, shock } \\
(p<0.001), \text { acute } \\
\text { myocardial injury } \\
(p=0.002), \text { and } \\
\text { secondary infection } \\
(p=0.002) \text {. Rating: Good. } \\
\text { No correlation with acute } \\
\text { liver dysfunction } \\
(p=0.820), \text { acute kidney } \\
\text { injury }(p=0.172), \\
\text { embolization/thrombosis } \\
(p=0.281), \text { or } \\
\text { pneumothorax } \\
(p=0.856) .\end{array}$ & $\begin{array}{c}\text { Nutritional } \\
\text { risk correlated } \\
\text { with death in } \\
\text { the ICU after } \\
28 \text { days } \\
(p<0.001) . \\
\text { Rating: Good. }\end{array}$ \\
\hline
\end{tabular}

Abbreviations: ARDS, acute respiratory distress syndrome; AUC, Area Under the Curve; CI, Confidence Interval; CNY, Chinese Yuan; COVID-19, coronavirus disease 2019; ICU, intensive Nutritional Risk Index; NRS-2002, Nutritional Risk Screening 2002; NST, Nutritional Screening Tool. 


\section{Discussion}

To our knowledge, this is the first systematic review to verify the nutritional screening tools used to identify nutritional risk in older adults with COVID-19. The instruments evaluated in this review can be considered useful for assessing nutritional risk in older adults with COVID-19. Although the majority (except the MUST) demonstrated low specificity, they showed high sensitivity and/or good predictive validity. The NRS-2002 was the only instrument to demonstrate a sensitivity of $100 \%$ compared to BMI and greater than $90 \%$ compared to three other nutritional screening instruments (the MNA-sf, MUST, and NRI). However, the MUST demonstrated better specificity. The MNA and the MUST showed better criterion validity. When tools with high sensitivity and specificity are not available, high sensitivity to identify risk is the preferable criterion for selecting a screening instrument because this is essential for directing individualized nutritional management with a focus on improving the patient's nutritional status $[47,48]$.

Different nutritional screening instruments identified different prevalence rates of nutritional risk. Liu et al. [46] found a prevalence of $85.1 \%$ using the NRS-2002, but only $41.1 \%$ using the MUST. Previous studies have also reported overestimation by the NRS-2002 in identifying nutritional risk in older individuals [21,49]. For example, Poulia et al. [21] found that the NRS-2002 showed greater sensitivity $(99 \%)$ and less specificity $(6.1 \%)$ when identifying nutritional risk in older adults compared to the NRI, GNRI, MNA-sf, MUST, and SGA.

The evaluation criteria of the NRS-2002 and MUST can explain the wide difference in the prevalence of nutritional risk they report in older adults with COVID-19. The Multinational Consensus Statement from the Fleischner Society reports that patients with moderate and severe clinical conditions can present significant lung dysfunction or damage [50]. Chen et al. [51] have reported that $43.6 \%$ of older adults with COVID-19 had severe conditions at hospital admission, and $43.6 \%$ were critical cases. Likewise, in a study that evaluated 24 COVID-19 patients in critical condition, all were admitted to the ICU with hypoxemic respiratory failure and with $75 \%$ requiring mechanical ventilation [52]. The severe respiratory condition of most patients hospitalized with COVID-19 may favor higher scores in terms of disease severity ( 2 or 3 points). This, in turn, can affect the NRS-2002's identification of nutritional risk in these patients. This can be seen in a study by Zhao et al. [53], which included 371 young adults and older adults with COVID-19 in severe and critical condition. Disease severity was scored as 2 points for $99 \%$ of the patients in severe condition ( 307 of 310 ) and 3 points (the maximum) for $100 \%$ (61) of the patients in critical condition.

In the nutritional score domain of the NRS-2002, patients receive 1 point if they demonstrate weight loss greater than $5 \%$ in the last three months, or food intake between $50 \%$ and $75 \%$ of nutritional needs (from a maximum score of 3 ). These conditions are common among older adults with COVID-19, which may explain the impact of this domain in characterizing nutritional risk (score $\geq 3$ ) according to the NRS-2002 [14]. For older adults over 70, an additional point is awarded for weight loss of more than $5 \%$ in the last three months or food intake between $50 \%$ and $75 \%$ of nutritional needs, leading to a diagnosis of nutritional risk [14].

The MUST, in contrast, has three domains: BMI, weight loss, and consequences of disease severity. Inclusion of BMI as a parameter for classifying nutritional risk may represent limited applicability of this nutritional screening instrument for hospitalized older adults; it is difficult to measure weight and height, needed to calculate BMI, in bedridden patients [9,54]. Furthermore, there are still limitations in the accuracy and precision of the weight and height estimation equations used for nutritional assessment among older adults [55].

The MUST is assigned a point in the BMI domain for people with a BMI less than $20 \mathrm{~kg} / \mathrm{m}^{2}$. Several studies have reported a high prevalence of overweight and obesity among patients with COVID-19, with few older adults with COVID-19 having low weight [56,57]. In a study including 37 patients with a mean age over 60 years, 23 were overweight $\left(B M I>24.9 \mathrm{~kg} / \mathrm{m}^{2}\right), 13$ were adequate weight (BMI between 18.5 and $24.9 \mathrm{~kg} / \mathrm{m}^{2}$ ), and only 1 was underweight $\left(\mathrm{BMI}<18.5 \mathrm{~kg} / \mathrm{m}^{2}\right.$ ) [57]. Because the MUST is applied on admission and weight loss is more visible during hospitalization, it could be that 
few older adults with COVID-19 meet this criterion [58]. Furthermore, the MUST's low BMI cut-off point may not be adequate to identify nutritional risk related to weight loss in older adults, because the optimal BMI is higher in this population than the optimum proposed for young adults [9].

In the weight loss domain, points are only awarded if weight loss is between $5 \%$ and $10 \%$ in the last three to six months. This criterion can also be difficult to identify in some people with COVID-19, considering that many times, the people does not know how to provide this information, or the records are not available on the patient's admission. Furthermore, COVID-19 can worsen very quickly in older adults [59]. Wang et al. [59] found that older Chinese with COVID-19 showed rapid disease progression, with an average duration of 11.5 days from first symptoms to death. Thus, weight loss above $5 \%$ may not occur before hospital admission.

The disease severity domain is assigned 2 points for people with a drastic reduction of food consumption or inability to eat on more than five days. Chen et al. [51] found that $9.1 \%$ of older adults with COVID-19 experienced anorexia. Thus, this area could be assigned a low score before these symptoms are present and severe enough to fulfill the criterion.

mNUTRIC scores showed poor construct validity when compared to albumin, pre-albumin, creatinine, and TLC levels. Despite disagreement among researchers on the use of these laboratory parameters to assess the validity of nutritional screening instruments, some studies have reported them to associate with the diagnosis of nutritional risk $[60,61]$, and other systematic reviews have used them for the analysis of construct validity $[9,36,38]$. These parameters are also included in some instruments, such as CONUT [62], the Nutrition Screening Equation [63], the GNRI [13], and the NRI [16].

These laboratory parameters are influenced by several factors, including inflammation and acute disease [64-67]. Zhang et al. [43] recorded low concentrations of albumin, pre-albumin, and TLC in people with both high and low nutritional risk. This may have been because the mNUTRIC score is an instrument for critically ill patients, and a severe inflammatory condition is recorded for people with COVID-19 in this context [68,69].

Many authors question the validity of albumin as an indicator of nutritional status because it has a half-life of 20 days [70,71], whereas other researchers consider this half-life applicable under normal physiological conditions. In cases of disease, including infection, the half-life of albumin can be reduced [72,73]. Thus, analysis of albumin concentrations requires caution, especially in people with COVID-19 who have been administered corticosteroids, which can further modify albumin concentrations $[74,75]$.

The prevalence of nutritional risk was high in all studies, ranging from $27.5 \%$ [44] to $100 \%$ [45]. Only one study evaluated actual malnutrition, identifying a prevalence of $52.7 \%$ [44]. These prevalence rates are higher than those recorded in previous literature regarding hospitalized older adults [20,23], including Chinese adults [76]. A previous systematic review identified a $22.0 \%$ prevalence of malnutrition in hospitalized older adults based on the MNA [20]. In contrast, Li et al. [44], who also used the MNA, identified a 52.7\% prevalence of malnutrition in older adults with COVID-19, in addition to $27.5 \%$ prevalence of nutritional risk. Another previous study involving 339 older people in Nepal identified a $49.6 \%$ prevalence of nutritional risk and a $24.8 \%$ prevalence of malnutrition [77].

Using the NRS-2002, Liu et al. [46] identified an $85.1 \%$ prevalence of nutritional risk among older adults with COVID-19. This is higher than the prevalence recorded by Zhang et al. [78], who also used the NRS-2002, but in a study that included 536 hospitalized patients with different diseases. Another study using the NRS-2002, included 114 Chinese with gastric cancer, a clinical condition that leads to severe catabolism, identified a $70.1 \%$ prevalence of nutritional risk [76], and a systematic review including studies of European patients hospitalized for various diseases found a prevalence of $41.5 \%$ [23].

$\mathrm{Li}$ et al. [44], who evaluated the association between comorbidities and nutritional risk [43,46], found an association between diabetes mellitus and nutritional risk. No significant associations were identified with other comorbidities analyzed in the studies. Diabetes mellitus is associated with greater nutritional risk in the older population in general [79]. Paris et al. [80] identified a 39.1\% prevalence of 
nutritional risk in older hospitalized patients with diabetes, and a $21.2 \%$ prevalence of malnutrition. Diabetes mellitus is also a risk factor for COVID-19 progression and worse prognosis [81,82]. Thus, particular focus should be directed toward the nutritional screening process of hospitalized older adults with COVID-19 with comorbid diabetes mellitus, many of whom may also be obese, another risk factor for worsening the disease [83,84]. In a systematic review, 38 of the 44 studies reported a prevalence of obesity above $38 \%$ in hospitalized patients with an average age between 50 and 70 years and diabetes mellitus [85]. Considering that both diabetes and nutritional risk relate to worsening progression of COVID-19, it is important that personalized nutritional therapy for older adults with COVID-19 considers all these factors $[7,27,59]$.

Accordingly, considering BMI alone or as the primary criterion in nutritional screening may neglect or underestimate nutritional risk among people with COVID-19 with a high BMI [86]. In the study by Liu et al. [46], for example, overweight people were diagnosed with nutritional risk according to the NRS-2002, MUST, MNA- sf, and NRI. This highlights the importance of using nutritional screening tools to identify nutritional risk in older adults with COVID-19, regardless of BMI.

Liu et al. [46] found that a diagnosis of nutritional risk using the NRS-2002, NRI, and MNA-sf predicted longer hospital stays, worse disease, worse appetite, and greater weight change as compared to no nutritional risk. mNUTRIC score predicted complications in the ICU such as ARDS, shock, acute myocardial injury, secondary infection, and mortality after 28 days of hospitalization. The good predictive validity of the mNUTRIC score for ICU complications can be explained by the fact that this instrument was developed to screen for nutritional risk in critically ill patients, with a focus on identifying clinical complications related to nutritional risk [18,87]. Thus, the good predictive validity of mNUTRIC scores can contribute to better monitoring of patients' prognosis and more effective treatment by the health team.

The predictive validity of the screening instruments was weak or poor for other factors, except for the MNA-sf, which showed good predictive validity for poor appetite and weight change, and the mNUTRIC score, which showed good predictive validity for mortality in the ICU after 28 days of hospitalization. A diagnosis of nutritional risk according to the MUST predicted only poor appetite and weight change. This may be related to the evaluation criteria of this instrument, which include changes in body weight and appetite (reduction of food consumption) as important factors. Several previous studies have also reported on the predictive validity of nutritional screening instruments for various clinical outcomes [88-91].

In addition to assessing older people' nutritional risk upon hospital admission and during treatment of COVID-19, follow-up after improvement of or recovery from the disease with remission of pneumonia is necessary. A study including 50 young and older adult patients in a hospital unit and in rehabilitation after recovery from COVID-19 identified that 45\% were at high nutritional risk and $26 \%$ were at moderate risk, according to MUST criteria [92].

During the COVID-19 pandemic, with the adoption of physical distancing measures, situations may arise that require new approaches to nutritional screening of older adults who have recovered from the disease. For countries in which telemedicine is authorized, nutritional screening can be conducted at a distance. To this end, Krznarić et al. [93] proposed a simple and practical protocol for assessing malnutrition in adult and older adults. The Remote Malnutrition App (R-MAPP) includes assessment of nutritional risk with MUST adaptation and can be used in primary health care settings.

This systematic review presents the strengths and weaknesses of various instruments used to assess nutritional risk in older adults with COVID-19. However, some limitations must be considered. First, all the included studies were conducted in China. Caution is required when extrapolating the results to other populations. Second, the sample sizes in the four studies were small, and selection was not random or consecutive. Third, there was no standardization among the studies regarding the gold standard diagnostic criterion for COVID-19 (RT-PCR test). Finally, because the studies were not prospective and controlled, confusion and selection biases may have influenced the results, and there is no way to infer causality regarding the diagnosis of COVID-19 and nutritional risk or malnutrition. 


\section{Conclusions}

Nutritional risk was highly prevalent among older adults with COVID-19 regardless of the nutritional screening tool applied. The NRS-2002, MNA, MNA-sf, NRI, and MUST showed high sensitivity, but only the MUST demonstrated better specificity compared to BMI. Of the various instruments used in the studies, the MNA and MUST presented the best criterion validity. The MNA-sf had the best predictive validity for poor appetite and weight loss over $2.6 \mathrm{~kg}$, and the NRS-2002 had the best predictive validity for the length of hospital stay. mNUTRIC score had good predictive validity for complications in the ICU such as ARDS, shock, acute myocardial injury, secondary infection, and mortality after 28 days of hospitalization.

Considering their convenience, low cost, and good ability to predict clinical outcomes, nutritional screening and assessment tools can contribute to the early diagnosis of people with greater nutritional risk. Because nutritional risk is a modifiable factor that can be reduced or controlled with early, individualized nutritional therapy, identifying risk using instruments with adequate sensitivity can help prevent worsening disease and improve patients' prognoses.

Supplementary Materials: The following are available online at http://www.mdpi.com/2072-6643/12/10/2956/s1, Table S1: Detailed search strategy for systematic review.

Author Contributions: Conceptualization, D.F.O.S., S.C.V.C.L., K.C.M.S.-E., D.M.M., R.N.C. and F.B.d.A.; methodology, D.F.O.S., R.N.C. and S.C.V.C.L.; software, D.F.O.S.; formal analysis, D.F.O.S., S.C.V.C.L. and R.N.C.; investigation, D.F.O.S. and S.C.V.C.L.; data curation, D.F.O.S. and S.C.V.C.L.; writing-original draft preparation, D.F.O.S.; writing-review and editing, D.F.O.S., S.C.V.C.L., K.C.M.S.-E., D.M.M. and F.B.d.A.; visualization, D.F.O.S. and S.C.V.C.L.; supervision, S.C.V.C.L. and F.B.d.A. All authors have read and agreed to the published version of the manuscript.

Funding: This study was financed in part by the Coordenação de Aperfeiçoamento de Pessoal de Nível Superior - Brasil (CAPES) - Finance Code 001. The funders had no role in study design, data collection and analysis, decision to publish, or preparation of the manuscript.

Conflicts of Interest: The authors declare no conflict of interest.

\section{References}

1. World Health Organization. Coronavirus Disease 2019 (COVID-19). Situation Report-206. Available online: https://www.who.int/docs/default-source/coronaviruse/situation-reports/20200813-covid-19-sitrep206.pdf?sfvrsn=bf38f66b_6 (accessed on 14 August 2020).

2. Zheng, Z.; Peng, F.; Xu, B.; Zhao, J.; Liu, H.; Peng, J.; Li, Q.; Jiang, C.; Zhou, Y.; Liu, S.; et al. Risk factors of critical \& mortal COVID-19 cases: A systematic literature review and meta-analysis. J. Infect. 2020, 81, e16-e25. [CrossRef] [PubMed]

3. Fu, L.; Wang, B.; Yuan, T.; Chen, X.; Ao, Y.; Fitzpatrick, T.; Li, P.; Zhou, Y.; Lin, Y.F.; Duan, Q.; et al. Clinical characteristics of coronavirus disease 2019 (COVID-19) in China: A systematic review and meta-analysis. J. Infect. 2020, 80, 656-665. [CrossRef] [PubMed]

4. Liu, K.; Chen, Y.; Lin, R.; Han, K. Clinical features of COVID-19 in elderly patients: A comparison with young and middle-aged patients. J. Infect. 2020, 80, e14-e18. [CrossRef] [PubMed]

5. Mehta, P.; McAuley, D.F.; Brown, M.; Sanchez, E.; Tattersall, R.S.; Manson, J.J. HLH Across Speciality Collaboration. COVID-19: Consider cytokine storm syndromes and immunosuppression. Lancet 2020, 395, 1033-1034. [CrossRef]

6. Zabetakis, I.; Lordan, R.; Norton, C.; Tsoupras, A. COVID-19: The Inflammation Link and the Role of Nutrition in Potential Mitigation. Nutrients 2020, 12, 1466. [CrossRef] [PubMed]

7. Handu, D.; Moloney, L.; Rozga, M.; Cheng, F. Malnutrition Care during the COVID-19 Pandemic: Considerations for Registered Dietitian Nutritionists Evidence Analysis Center. J. Acad. Nutr. Diet. 2020, in press. [CrossRef]

8. Lochs, H.; Allison, S.P.; Meier, R.; Pirlich, M.; Kondrup, J.; van den Berghe, G.; Pichard, C. Introductory to the ESPEN guidelines on enteral nutrition: Terminology, definitions and general topics. Clin. Nutr. 2006, 25, 180-186. [CrossRef] 
9. Dent, E.; Hoogendijk, E.O.; Visvanathan, R.; Wright, O. Malnutrition Screening and Assessment in Hospitalised Older People: A Review. J. Nutr. Health Aging. 2019, 23, 431-441. [CrossRef]

10. Cereda, E.; Veronese, N.; Caccialanza, R. The final word on nutritional screening and assessment in older persons. Curr. Opin. Clin. Nutr. Metab. Care 2018, 21, 24-29. [CrossRef]

11. Rubenstein, L.Z.; Harker, J.O.; Salvà, A.; Guigoz, Y.; Vellas, B. Screening for undernutrition in geriatric practice: Developing the short-form mini-nutritional assessment (MNA-SF). J. Gerontol. A Biol. Sci. Med. Sci. 2001, 56, M366-M372. [CrossRef]

12. Kaiser, M.J.; Bauer, J.M.; Ramsch, C.; Uter, W.; Guigoz, Y.; Cederholm, T.; Thomas, D.R.; Anthony, P.; Charlton, K.E.; Maggio, M.; et al. MNA-International Group Validation of the Mini Nutritional Assessment short-form (MNA-SF): A practical tool for identification of nutritional status. J. Nutr. Health Aging 2009, 13, 782-788. [CrossRef] [PubMed]

13. Bouillanne, O.; Morineau, G.; Dupont, C.; Coulombel, I.; Vincent, J.P.; Nicolis, I.; Benazeth, S.; Cynober, L.; Aussel, C. Geriatric Nutritional Risk Index: A new index for evaluating at-risk elderly medical patients. Am. J. Clin. Nutr. 2005, 82, 777-783. [CrossRef] [PubMed]

14. Kondrup, J.; Rasmussen, H.H.; Hamberg, O.; Stanga, Z.; Ad Hoc ESPEN Working Group. Nutritional risk screening (NRS 2002): A new method based on an analysis of controlled clinical trials. Clin. Nutr. 2003, 22, 321-336. [CrossRef]

15. Stratton, R.J.; Hackston, A.; Longmore, D.; Dixon, R.; Price, S.; Stroud, M.; King, C.; Elia, M. Malnutrition in hospital outpatients and inpatients: Prevalence, concurrent validity and ease of use of the 'malnutrition universal screening tool' ('MUST') for adults. Br. J. Nutr. 2004, 92, 799-808. [CrossRef]

16. Buzby, G.P.; Williford, W.O.; Peterson, O.L.; Crosby, L.O.; Page, C.P.; Reinhardt, G.F.; Mullen, J.L. A randomized clinical trial of total parenteral nutrition in malnourished surgical patients: The rationale and impact of previous clinical trials and pilot study on protocol design. Am. J. Clin. Nutr. 1988, 47, 357-365. [CrossRef] [PubMed]

17. Kruizenga, H.M.; Seidell, J.C.; de Vet, H.C.; Wierdsma, N.J. Development and validation of a hospital screening tool for malnutrition: The short nutritional assessment questionnaire (SNAQ). Clin. Nutr. 2005, 24, 75-82. [CrossRef]

18. Heyland, D.K.; Dhaliwal, R.; Jiang, X.; Day, A.G. Identifying critically ill patients who benefit the most from nutrition therapy: The development and initial validation of a novel risk assessment tool. Crit. Care 2011, 15, R268. [CrossRef]

19. Vellas, B.; Villars, H.; Abellan, G.; Soto, M.E.; Rolland, Y.; Guigoz, Y.; Morley, J.E.; Chumlea, W.; Salva, A.; Rubenstein, L.Z.; et al. Overview of the MNA-Its history and challenges. J. Nutr. Health Aging 2006, 10, 456-465.

20. Cereda, E.; Pedrolli, C.; Klersy, C.; Bonardi, C.; Quarleri, L.; Cappello, S.; Turri, A.; Rondanelli, M.; Caccialanza, R. Nutritional status in older persons according to healthcare setting: A systematic review and meta-analysis of prevalence data using MNA ${ }^{\circledR}$. Clin. Nutr. 2016, 35, 1282-1290. [CrossRef]

21. Poulia, K.A.; Yannakoulia, M.; Karageorgou, D.; Gamaletsou, M.; Panagiotakos, D.B.; Sipsas, N.V.; Zampelas, A. Evaluation of the efficacy of six nutritional screening tools to predict malnutrition in the elderly. Clin. Nutr. 2012, 31, 378-385. [CrossRef]

22. Detsky, A.S.; McLaughlin, J.R.; Baker, J.P.; Johnston, N.; Whittaker, S.; Mendelson, R.A.; Jeejeebhoy, K.N. What is subjective global assessment of nutritional status? JPEN J. Parenter. Enter. Nutr. 1987, 11, 8-13. [CrossRef] [PubMed]

23. Leij-Halfwerk, S.; Verwijs, M.H.; van Houdt, S.; Borkent, J.W.; Guaitoli, P.R.; Pelgrim, T.; Heymans, M.W.; Power, L.; Visser, M.; Corish, C.A.; et al. Prevalence of protein-energy malnutrition risk in European older adults in community, residential and hospital settings, according to 22 malnutrition screening tools validated for use in adults $\geq 65$ years: A systematic review and meta-analysis. Maturitas 2019, 126, 80-89. [CrossRef] [PubMed]

24. Sheean, P.M.; Peterson, S.J.; Chen, Y.; Liu, D.; Lateef, O.; Braunschweig, C.A. Utilizing multiple methods to classify malnutrition among elderly patients admitted to the medical and surgical intensive care units (ICU). Clin. Nutr. 2013, 32, 752-757. [CrossRef] [PubMed]

25. Cascio, B.L.; Logomarsino, J.V. Evaluating the effectiveness of five screening tools used to identify malnutrition risk in hospitalized elderly: A systematic review. Geriatr. Nurs. 2018, 39, 95-102. [CrossRef] 
26. Zhang, Z.; Pereira, S.L.; Luo, M.; Matheson, E.M. Evaluation of Blood Biomarkers Associated with Risk of Malnutrition in Older Adults: A Systematic Review and Meta-Analysis. Nutrients 2017, 9, 829. [CrossRef]

27. Laviano, A.; Koverech, A.; Zanetti, M. Nutrition support in the time of SARS-CoV-2 (COVID-19). Nutrition 2020, 74, 110834. [CrossRef]

28. Moher, D.; Liberati, A.; Tetzlaff, J.; Altman, D.G.; PRISMA Group. Preferred reporting items for systematic reviews and meta-analyses: The PRISMA statement. Ann. Intern. Med. 2009, 151, 264-269. [CrossRef]

29. Wells, G.A.; Shea, B.; O'Connell, D.; Peterson, J.; Welch, V.; Losos, M.; Tugwell, P. The Newcastle-Ottawa Scale (NOS) for Assessing the Quality of Nonrandomised Studies in Meta-Analyses. Available online: http://www.ohri.ca/programs/clinical_epidemiology/oxford.asp (accessed on 20 December 2017).

30. The Modified Newcastle Ottawa Scale for Cross Sectional Studies. Available online: http://journals.plos.org/ plosone/article/file?id=info\%3Adoi/10.1371/journal.pone.0136065.s004\&type=supplementary (accessed on 20 December 2017).

31. Murad, M.H.; Sultan, S.; Haffar, S.; Bazerbachi, F. Methodological quality and synthesis of case series and case reports. BMJ Evid. Based Med. 2018, 23, 60-63. [CrossRef]

32. Whiting, P.F.; Rutjes, A.W.; Westwood, M.E.; Mallett, S.; Deeks, J.J.; Reitsma, J.B.; Leeflang, M.M.; Sterne, J.A.; Bossuyt, P.M.; QUADAS-2 Group. QUADAS-2: A revised tool for the quality assessment of diagnostic accuracy studies. Ann. Intern. Med. 2011, 155, 529-536. [CrossRef]

33. Skipper, A.; Ferguson, M.; Thompson, K.; Castellanos, V.H.; Porcari, J. Nutrition screening tools: An analysis of the evidence. JPEN J. Parenter. Enter. Nutr. 2012, 36, 292-298. [CrossRef]

34. Håkonsen, S.J.; Pedersen, P.U.; Bath-Hextall, F.; Kirkpatrick, P. Diagnostic test accuracy of nutritional tools used to identify undernutrition in patients with colorectal cancer: A systematic review. JBI Database Syst. Rev. Implement. Rep. 2015, 13, 141-187. [CrossRef]

35. Boléo-Tomé, C.; Monteiro-Grillo, I.; Camilo, M.; Ravasco, P. Validation of the Malnutrition Universal Screening Tool (MUST) in cancer. Br. J. Nutr. 2012, 108, 343-348. [CrossRef] [PubMed]

36. Guaitoli, P.R.; Jansma, E.P.; de Vet, H.C. Nutrition screening tools: Does one size fit all? A systematic review of screening tools for the hospital setting. Clin. Nutr. 2014, 33, 39-58. [CrossRef] [PubMed]

37. De Groot, L.M.; Lee, G.; Ackerie, A.; van der Meij, B.S. Malnutrition Screening and Assessment in the Cancer Care Ambulatory Setting: Mortality Predictability and Validity of the Patient-Generated Subjective Global Assessment Short form (PG-SGA SF) and the GLIM Criteria. Nutrients 2020, 12, 2287. [CrossRef] [PubMed]

38. Miller, J.; Wells, L.; Nwulu, U.; Currow, D.; Johnson, M.J.; Skipworth, R. Validated screening tools for the assessment of cachexia, sarcopenia, and malnutrition: A systematic review. Am. J. Clin. Nutr. 2018, 108, 1196-1208. [CrossRef] [PubMed]

39. Seltzer, M.H.; Bastidas, J.A.; Cooper, D.M.; Engler, P.; Slocum, B.; Fletcher, H.S. Instant nutritional assessment. JPEN J. Parenter. Enter. Nutr. 1979, 3, 157-159. [CrossRef]

40. Swets, J.A. Measuring the accuracy of diagnostic systems. Science 1988, 240, 1285-1293. [CrossRef]

41. de Vries, M.C.; Koekkoek, W.K.; Opdam, M.H.; van Blokland, D.; van Zanten, A.R. Nutritional assessment of critically ill patients: Validation of the modified NUTRIC score. Eur. J. Clin. Nutr. 2018, 72, 428-435. [CrossRef]

42. Jouneau, S.; Kerjouan, M.; Rousseau, C.; Lederlin, M.; Llamas-Guttierez, F.; De Latour, B.; Guillot, S.; Vernhet, L.; Desrues, B.; Thibault, R. What are the best indicators to assess malnutrition in idiopathic pulmonary fibrosis patients? A cross-sectional study in a referral center. Nutrition 2019, 62, 115-121. [CrossRef]

43. Zhang, P.; He, Z.; Yu, G.; Peng, D.; Feng, Y.; Ling, J.; Wang, Y.; Li, S.; Bian, Y. The modified NUTRIC score can be used for nutritional risk assessment as well as prognosis prediction in critically ill COVID-19 patients. Clin. Nutr. 2020, in press. [CrossRef]

44. Li, T.; Zhang, Y.; Gong, C.; Wang, J.; Liu, B.; Shi, L.; Duan, J. Prevalence of malnutrition and analysis of related factors in elderly patients with COVID-19 in Wuhan, China. Eur. J. Clin. Nutr. 2020, 74, 871-875. [CrossRef] [PubMed]

45. Yuan, Y.; Wang, N.; Ou, X. Caution should be exercised for the detection of SARS-CoV-2, especially in the elderly. J. Med. Virol. 2020, 74, 1641-1648. [CrossRef] [PubMed]

46. Liu, G.; Zhang, S.; Mao, Z.; Wang, W.; Hu, H. Clinical significance of nutritional risk screening for older adult patients with COVID-19. Eur. J. Clin. Nutr. 2020, 74, 876-883. [CrossRef] [PubMed] 
47. Abbott, J.; Teleni, L.; McKavanagh, D.; Watson, J.; McCarthy, A.L.; Isenring, E. Patient-Generated Subjective Global Assessment Short Form (PG-SGA SF) is a valid screening tool in chemotherapy outpatients. Support. Care Cancer 2016, 24, 3883-3887. [CrossRef] [PubMed]

48. Tran, Q.C.; Banks, M.; Hannan-Jones, M.; Do, T.; Gallegos, D. Validity of four nutritional screening tools against subjective global assessment for inpatient adults in a low-middle income country in Asia. Eur. J. Clin. Nutr. 2018, 72, 979-985. [CrossRef]

49. Poulia, K.A.; Klek, S.; Doundoulakis, I.; Bouras, E.; Karayiannis, D.; Baschali, A.; Passakiotou, M.; Chourdakis, M. The two most popular malnutrition screening tools in the light of the new ESPEN consensus definition of the diagnostic criteria for malnutrition. Clin. Nutr. 2017, 36, 1130-1135. [CrossRef]

50. Rubin, G.D.; Ryerson, C.J.; Haramati, L.B.; Sverzellati, N.; Kanne, J.P.; Raoof, S.; Schluger, N.W.; Volpi, A.; Yim, J.J.; Martin, I.; et al. The Role of Chest Imaging in Patient Management during the COVID-19 Pandemic: A Multinational Consensus Statement From the Fleischner Society. Chest 2020, 158, 106-116. [CrossRef]

51. Chen, T.; Dai, Z.; Mo, P.; Li, X.; Ma, Z.; Song, S.; Chen, X.; Luo, M.; Liang, K.; Gao, S.; et al. Clinical characteristics and outcomes of older patients with coronavirus disease 2019 (COVID-19) in Wuhan, China (2019): A single-centered, retrospective study. J. Gerontol. A Biol. Sci. Med. Sci. 2020, 75, 1788-1795. [CrossRef]

52. Bhatraju, P.K.; Ghassemieh, B.J.; Nichols, M.; Kim, R.; Jerome, K.R.; Nalla, A.K.; Greninger, A.L.; Pipavath, S.; Wurfel, M.M.; Evans, L.; et al. Covid-19 in Critically Ill Patients in the Seattle Region-Case Series. N. Engl. J. Med. 2020, 382, 2012-2022. [CrossRef]

53. Zhao, X.; Li, Y.; Ge, Y.; Shi, Y.; Lv, P.; Zhang, J.; Fu, G.; Zhou, Y.; Jiang, K.; Lin, N.; et al. Evaluation of Nutrition Risk and Its Association With Mortality Risk in Severely and Critically Ill COVID-19 Patients. JPEN J. Parenter. Enter. Nutr. 2020, in press. [CrossRef]

54. Cook, Z.; Kirk, S.; Lawrenson, S.; Sandford, S. Use of BMI in the assessment of undernutrition in older subjects: Reflecting on practice. Proc. Nutr. Soc. 2005, 64, 313-317. [CrossRef] [PubMed]

55. Souza, R.; Fraga, J.S.; Gottschall CB, A.; Busnello, F.M.; Rabito, E.I. Avaliação antropométrica em idosos: Estimativas de peso e altura e concordância entre classificações de IMC. Rev. Bras. Geriatr. Gerontol. 2013, 16, 81-90. [CrossRef]

56. Hajifathalian, K.; Kumar, S.; Newberry, C.; Shah, S.; Fortune, B.; Krisko, T.; Ortiz-Pujols, S.; Zhou, X.K.; Dannenberg, A.J.; Kumar, R.; et al. Obesity is associated with worse outcomes in COVID-19: Analysis of Early Data From New York City. Obesity 2020, 28, 1606-1612. [CrossRef] [PubMed]

57. Higham, A.; Singh, D. Increased ACE2 Expression in Bronchial Epithelium of COPD Patients who are Overweight. Obesity 2020, 28, 1586-1589. [CrossRef] [PubMed]

58. Allard, J.P.; Keller, H.; Jeejeebhoy, K.N.; Laporte, M.; Duerksen, D.R.; Gramlich, L.; Payette, H.; Bernier, P.; Davidson, B.; Teterina, A.; et al. Decline in nutritional status is associated with prolonged length of stay in hospitalized patients admitted for 7 days or more: A prospective cohort study. Clin. Nutr. 2016, 35, 144-152. [CrossRef]

59. Wang, W.; Tang, J.; Wei, F. Updated understanding of the outbreak of 2019 novel coronavirus (2019-nCoV) in Wuhan, China. J. Med. Virol. 2020, 92, 441-447. [CrossRef]

60. González Madroño, A.; Mancha, A.; Rodríguez, F.J.; de Ulibarri, J.I.; Culebras, J. The use of biochemical and immunological parameters in nutritional screening and assessment. Nutr. Hosp. 2011, 26, 594-601. [CrossRef]

61. Lomivorotov, V.V.; Efremov, S.M.; Boboshko, V.A.; Nikolaev, D.A.; Vedernikov, P.E.; Lomivorotov, V.N.; Karaskov, A.M. Evaluation of nutritional screening tools for patients scheduled for cardiac surgery. Nutrition 2013, 29, 436-442. [CrossRef]

62. Ignacio de Ulíbarri, J.; González-Madroño, A.; de Villar, N.G.; González, P.; González, B.; Mancha, A.; Rodríguez, F.; Fernández, G. CONUT: A tool for controlling nutritional status. First validation in a hospital population. Nutr. Hosp. 2005, 20, 38-45.

63. Elmore, M.F.; Wagner, D.R.; Knoll, D.M.; Eizember, L.; Oswalt, M.A.; Glowinski, E.A.; Rapp, P.A. Developing an effective adult nutrition screening tool for a community hospital. J. Am. Diet. Assoc. 1994, 94, 1113-1120. [CrossRef]

64. Arroyo, V.; García-Martinez, R.; Salvatella, X. Human serum albumin, systemic inflammation, and cirrhosis. J. Hepatol. 2014, 61, 396-407. [CrossRef] [PubMed] 
65. Hrnciarikova, D.; Juraskova, B.; Hyspler, R.; Solichova, D.; Ticha, A.; Klemera, P.; Hronek, M.; Zadak, Z. A changed view of serum prealbumin in the elderly: Prealbumin values influenced by concomitant inflammation. Biomed. Pap. Med. Fac. Univ. Palacky Olomouc 2007, 151, 273-276. [CrossRef] [PubMed]

66. Nalbant, A.; Cinemre, H.; Kaya, T.; Varim, C.; Varim, P.; Tamer, A. Neutrophil to lymphocyte ratio might help prediction of acute myocardial infarction in patients with elevated serum creatinine. Pak. J. Med. Sci. 2016, 32, 106-110. [CrossRef] [PubMed]

67. Pasini, E.; Corsetti, G.; Aquilani, R.; Romano, C.; Picca, A.; Calvani, R.; Dioguardi, F.S. Protein-Amino Acid Metabolism Disarrangements: The Hidden Enemy of Chronic Age-Related Conditions. Nutrients 2018, 10, 391. [CrossRef]

68. Zhou, Y.; Fu, B.; Zheng, X.; Wang, D.; Zhao, C.; Qi, Y.; Sun, R.; Tian, Z.; Xu, X.; Wei, H. Pathogenic T-cells and inflammatory monocytes incite inflammatory storms in severe COVID-19 patients. Natl. Sci. Rev. 2020, 7, 998-1002. [CrossRef]

69. Aouba, A.; Baldolli, A.; Geffray, L.; Verdon, R.; Bergot, E.; Martin-Silva, N.; Justet, A. Targeting the inflammatory cascade with anakinra in moderate to severe COVID-19 pneumonia: Case series. Ann. Rheum. Dis. 2020, 79, 1381-1382. [CrossRef]

70. Fuhrman, M.P. The albumin-nutrition connection: Separating myth from fact. Nutrition 2020, 18, $199-200$. [CrossRef]

71. Fanali, G.; di Masi, A.; Trezza, V.; Marino, M.; Fasano, M.; Ascenzi, P. Human serum albumin: From bench to bedside. Mol. Aspects Med. 2012, 33, 209-290. [CrossRef]

72. de Ulíbarri Pérez, J.I.; Fernández, G.; Rodríguez Salvanés, F.; Díaz López, A.M. Nutritional screening; control of clinical undernutrition with analytical parameters. Nutr. Hosp. 2014, 29, 797-811. [CrossRef]

73. Soeters, P.B.; Wolfe, R.R.; Shenkin, A. Hypoalbuminemia: Pathogenesis and Clinical Significance. JPEN J. Parenter. Enter. Nutr. 2019, 43, 181-193. [CrossRef]

74. Fang, X.; Mei, Q.; Yang, T.; Li, L.; Wang, Y.; Tong, F.; Geng, S.; Pan, A. Low-dose corticosteroid therapy does not delay viral clearance in patients with COVID-19. J. Infect. 2020, 81, 147-178. [CrossRef] [PubMed]

75. Thorsdottir, I.; Gunnarsdottir, I.; Eriksen, B. Screening method evaluated by nutritional status measurements can be used to detect malnourishment in chronic obstructive pulmonary disease. J. Am. Diet. Assoc. 2001, 101, 648-654. [CrossRef]

76. Yang, D.; Zheng, Z.; Zhao, Y.; Zhang, T.; Liu, Y.; Xu, X. Patient-generated subjective global assessment versus nutritional risk screening 2002 for gastric cancer in Chinese patients. Future Oncol. 2020, 16, 4475-4483. [CrossRef] [PubMed]

77. Tamang, M.K.; Yadav, U.N.; Hosseinzadeh, H.; Kafle, B.; Paudel, G.; Khatiwada, S.; Sekaran, V.C. Nutritional assessment and factors associated with malnutrition among the elderly population of Nepal: A cross-sectional study. BMC Res. Notes 2019, 12, 246. [CrossRef]

78. Zhang, X.; Zhang, X.; Zhu, Y.; Tao, J.; Zhang, Z.; Zhang, Y.; Wang, Y.; Ke, Y.; Ren, C.; Xu, J. Predictive Value of Nutritional Risk Screening 2002 and Mini Nutritional Assessment Short Form in Mortality in Chinese Hospitalized Geriatric Patients. Clin. Interv. Aging 2020, 15, 441-449. [CrossRef]

79. Sanz-París, A.; Gómez-Candela, C.; Martín-Palmero, Á.; García-Almeida, J.M.; Burgos-Pelaez, R.; Matía-Martin, P.; Arbones-Mainar, J.M.; Study VIDA Group. Application of the new ESPEN definition of malnutrition in geriatric diabetic patients during hospitalization: A multicentric study. Clin. Nutr. 2016, 35, 1564-1567. [CrossRef]

80. Sanz París, A.; García, J.M.; Gómez-Candela, C.; Burgos, R.; Martín, Á.; Matía, P.; Study VIDA Group. Malnutrition prevalence in hospitalized elderly diabetic patients. Nutr. Hosp. 2013, 28, 592-599. [CrossRef]

81. Guo, W.; Li, M.; Dong, Y.; Zhou, H.; Zhang, Z.; Tian, C.; Qin, R.; Wang, H.; Shen, Y.; Du, K.; et al. Diabetes is a risk factor for the progression and prognosis of COVID-19. Diabetes Metab. Res. Rev. 2020, e3319, in press. [CrossRef]

82. Maddaloni, E.; Buzzetti, R. Covid-19 and diabetes mellitus: Unveiling the interaction of two pandemics. Diabetes Metab. Res. Rev. 2020, e33213321, in press. [CrossRef]

83. Dietz, W.; Santos-Burgoa, C. Obesity and its Implications for COVID-19 Mortality. Obesity 2020, $28,1005$. [CrossRef]

84. Stefan, N.; Birkenfeld, A.L.; Schulze, M.B.; Ludwig, D.S. Obesity and impaired metabolic health in patients with COVID-19. Nat. Rev. Endocrinol. 2020, 16, 341-342. [CrossRef] [PubMed] 
85. Colosia, A.D.; Palencia, R.; Khan, S. Prevalence of hypertension and obesity in patients with type 2 diabetes mellitus in observational studies: A systematic literature review. Diabetes Metab. Syndr. Obes. 2013, 6, 327-338. [CrossRef] [PubMed]

86. Yildirim, Z.G.; Uzunlulu, M.; Caklili, O.T.; Mutlu, H.H.; Oguz, A. Malnutrition rate among hospitalized patients with type 2 diabetes mellitus. Prog. Nutr. 2018, 20, 183-188. [CrossRef]

87. Rahman, A.; Hasan, R.M.; Agarwala, R.; Martin, C.; Day, A.G.; Heyland, D.K. Identifying critically-ill patients who will benefit most from nutritional therapy: Further validation of the "modified NUTRIC" nutritional risk assessment tool. Clin. Nutr. 2016, 35, 158-162. [CrossRef] [PubMed]

88. Thomas, J.; Kaambwa, B.; Delaney, C.; Miller, M. An evaluation of the validity of nutrition screening and assessment tools in patients admitted to a vascular surgery unit. Br. J. Nutr. 2019, 122, 689-697. [CrossRef]

89. Hersberger, L.; Bargetzi, L.; Bargetzi, A.; Tribolet, P.; Fehr, R.; Baechli, V.; Geiser, M.; Deiss, M.; Gomes, F.; Kutz, A.; et al. Nutritional risk screening (NRS 2002) is a strong and modifiable predictor risk score for short-term and long-term clinical outcomes: Secondary analysis of a prospective randomised trial. Clin. Nutr. 2020, 39, 2720-2729. [CrossRef]

90. Lew, C.; Yandell, R.; Fraser, R.; Chua, A.P.; Chong, M.; Miller, M. Association between Malnutrition and Clinical Outcomes in the Intensive Care Unit: A Systematic Review. JPEN J. Parenter. Enter. Nutr. 2017, 41, 744-758. [CrossRef]

91. Rabito, E.I.; Marcadenti, A.; da Silva Fink, J.; Figueira, L.; Silva, F.M. Nutritional Risk Screening 2002, Short Nutritional Assessment Questionnaire, Malnutrition Screening Tool, and Malnutrition Universal Screening Tool Are Good Predictors of Nutrition Risk in an Emergency Service. Nutr. Clin. Pract. 2017, 32, 526-532. [CrossRef]

92. Brugliera, L.; Spina, A.; Castellazzi, P.; Cimino, P.; Arcuri, P.; Negro, A.; Houdayer, E.; Alemanno, F.; Giordani, A.; Mortini, P.; et al. Nutritional management of COVID-19 patients in a rehabilitation unit. Eur. J. Clin. Nutr. 2020, 74, 860-863. [CrossRef]

93. Krznarić, Ž.; Bender, D.V.; Laviano, A.; Cuerda, C.; Landi, F.; Monteiro, R.; Pirlich, M.; Barazzoni, R. A simple remote nutritional screening tool and practical guidance for nutritional care in primary practice during the COVID-19 pandemic. Clin. Nutr. 2020, 39, 1983-1987. [CrossRef] 